Boško Mekinjić

Ekonomski fakultet Univerziteta u Banjoj Luci bosko.mekinjic@kombank-bl.com

Miloš Grujić

Penzijski rezervni fond Republike Srpske, Banja Luka milos.grujic@pref.rs.ba

Dragana Vujičić-Stefanović

Komercijalna banka a.d. Banja Luka

dragana.vujicic@kombank-bl.com

Prevod obezbedili autori
PRIMJENA REGRESIONE ANALIZE U PROCJENI UTICAJA DIGITALIZACIJE I TEHNOLOŠKIH INOVACIJA NA TRI MJERE RAZVOJA PRIVREDE I DRUŠTVA

\title{
Rezime
}

Cilj rada je da se ispita korelacija između dostignutog nivoa tehnologije i inovacija i razvoja finansijskog tržišta, indeksa humanog razvoja i bruto domaćeg proizvoda po glavi stanovnika. Istraživačko pitanje glasi: „Da li su, i u kakvoj vezi, nivo tehnologije i inovacija sa indeksom razvijenosti tržišta, indeksom ljudskog razvoja i BDP-om po glavi stanovnika?" Cilj istraživanja je da utvrdimo da li ima osnova za verovanje da je „,kopiranjem” određene zemlje po nivou digitalizacije i inovacija moguće dodatno razviti finansijsko tržište, uticati na nivo ljudskog razvoja ili na povećanje BDP-a po glavi stanovnika. Metode korištene u radu su regresiona analiza, odnosno prosta linearna regresija, te analiza i sinteza prethodnih istraživanja i teoretskih nalaza, da bi zaključci bili izvučeni metodom indukcije. Rad predstavlja doprinos autora ekonomskoj teoriji i praksi, te široj javnosti. Rezultati istraživanja još ukazuju i da bi bilo racionalno da finansijski posrednici u zemljama u razvoju razmotre izmjenu svojih poslovnih modela i mogućnosti za njihovo prilagođavanje ubrzanim tehnološkim promjenama.

Ključne reči: digitalizacija, inovacije, finansijska tržišta, FD indeks, HDI, BDP per capita 


\section{THE USE OF REGRESSION ANALYSIS IN THE EVALUATION OF THE IMPACT OF DIGITALISATION AND TECHNOLOGICAL INOVATIONS IN THREE MEASURES OF THE DEVELOPMENT OF ECONOMY AND SOCIETY}

Boško Mekinjić

Faculty of Economics University of Banja Luka bosko.mekinjic@kombank-bl.com

\section{Miloš Grujić}

The Pension Reserve Fund of Republika Srpska, Banja Luka milos.grujic@pref.rs.ba

\section{Dragana Vujičić-Stefanović}

Komercijalna banka

a.d. Banja Luka

dragana.vujicic@kombank-bl.com

\section{Summary}

The objective of this paper is to examine the correlation between the achieved level of technology and innovations and the development of the financial market, index of human development and gross domestic product per capita. The research question reads: "Is the level of technology and innovations related to the market development index, the human development index and GDP per capita, and in what way?" The research objective is to determine whether there is a reason to believe that, by imitating a certain country in relation to the level of digitalisation and innovations, it is possible to further develop the financial market, affect the level of human development or the increase in GDP per capita. Methods used in this paper are regression analysis, i.e. simple linear regression, as well as the analysis and consolidation of preceding research and theoretical findings in order for conclusions to be drawn through an induction method. The paper represents the authors' contribution to the theory and application of economics, as well as to the wider public. The research results also indicate that it would be rational for financial intermediaries in developing countries to consider changing their business models and new possibilities for their adjustment to accelerated technological changes.

Keywords: digitalisation, innovations, financial markets, FD index, HDI, BDP per capita 


\section{Uvod}

U protekla tri vijeka civilizacija je prošla kroz tri industrijske revolucije, dok je prema mišljenju vodećih svjetskih ekonomista u toku četvrta industrijska revolucija, ili kako se još popularno naziva i 4.0 industrija. Svaku od ovih industrijskih revolucija karakterisale su tehnološke inovacije koje su imale ključni uticaj na razvoj cjelokupnog čovječanstva. Industrija 4.0 već sada na različite načine utiče na sve poslovne aktivnosti, istovremeno razvijajući digitalne i ostale tehnologije, ali utiče i na cjelokupan stil života u svijetu. Nakon procesa globalizacije i povezivanja svijeta $\mathrm{u}$ jedno globalno tržište, koje je za posljedicu imalo nesmetano širenje poslovanja, započelo je novo doba koje možemo nazvati dobom digitalne transformacije. Osnovna karakteristika novog, digitalnog doba jeste što iz dana u dan poprima nove dimenzije i nove oblike. Ubrzan tehnološki razvoj, ekspanzija pametnih uređaja, omasovljavanje mobilnih uređaja kao neki od elemenata četvrte industrijske revolucije stavili su pred finansijske institucije izazove na koje su one odgovorile digitalizacijom, stvaranjem novih komunikacijskih kanala ka klijentima, kao i mnoštvom drugih inovativnih servisa (Šehović, 2017, 136).

Iako po svojoj strukturi, obliku poslovanja i ostalim karakteristikama, banke teže prihvataju promjene, ipak su u značajnoj mjeri svoje poslovanje prilagodile promjenama $u$ poslovnom okruženju i samim tim usvojile i primjenile određene procese koje nameće proces digitalizacije. Kontinuirani proces kreiranja novih bankarskih proizvoda i usluga koji su direktno vezani za proces digitalizacije, jasan su znak da je bankarski sektor ozbiljno shvatio nadolazeće promjene. Ove promjene za posljedicu imaju i stvaranje konkurentske prednosti i bolje pozicije na tržištu. Prema shvatanju stručnjaka, tehnološke inovacije i klijenti će postaviti "nova pravila igre“ u bankarskom sektoru (Ćukić, 2013), što će značajno uticati na banke, a posebno na one kod kojih je u velikoj mjeri izraženo tradicionalno bankarsko poslovanje (Tornjanski, V., Petrović, D., \& Milanović, M., 2016). Da bi banke održale svoju konkurentnost, rast i razvoj, te kontinuirano stvarale vrijednost za korisnike bankarskih usluga i akcionare, menadžment banaka treba da shvati ove trendove, te da redefiniše postojeće strategije poslovanja (Fasnacht, 2009; Huo i Hong, 2013; Tornjanski i saradnici, 2014) i razvije nove modele za prikupljanje znanja, bez odlaganja.

Dosadašnja istraživanja pokazuju da finansijske institucije i stanovništvo imaju značajne prednosti od procesa digitalizacije i inovacija (Laursen i Salter, 2006; Fasnacht, 2009). $S$ druge strane, uprkos tome što digitalizacija predstavlja važan korak za primjenu inovacija, u dosadašnjem naučnoistraživačkom fondu ne postoji dovoljno istraživanja o ovim procesima, odnosno o tome kako digitalizacija, inovacije i informaciono-komunikacione tehnologije doprinose performansama otvorenih inovacija u bankarstvu (Tornjanski et al., 2016). Imajući to u vidu, ovaj rad ima za cilj da produbi i proširi naučni fond o efektima digitalizacije i inovacija na finansijsko tržište i na stanovništvo, te da prikaže značaj ovih procesa.

Prva istraživačka hipoteza glasi: „Tehnologije i inovacije ne utiču na FD indeks."

Druga istraživačka hipoteza glasi: „Tehnologije i inovacije ne utiču na HDI."

Treća istraživačka hipoteza glasi: „Tehnologije i inovacije ne utiču na BDP per capita."

\section{Prethodno istraživanje}

Industrija 4.0 ili tzv. četvrta industrijska revolucija, odnosno digitalizacija industrije, već nekoliko godina je ključna tema u kojoj se traga za odgovorima kako privrede mogu da budu više konkurentne na globalnim tržištima (Mekinjić, 2019).

Suština industrije 4.0 je u novom pristupu, tj. umrežavanju pametnih digitalnih uređaja sa proizvodima, alatima, robotima i ljudima, dok su njen osnovni cilj pametne fabrike koje su prilagodljive i koje efikasno integrišu klijente i poslovne partnere $\mathrm{u}$ jedinstveni proces (Mekinjić, 2019). Na ovaj način bi se povećala produktivnost i efikasnost i time obezbijedila konkurentnost na globalnom tržištu. Jedna od zanimljivosti ove revolucije jeste što je ona zakazana unaprijed, tj. iz nužde usljed krize, recesije i usporavanja privredne aktivnosti, što je navelo vodeće države Evropske unije da traže 


\section{Introduction}

In the past three centuries, civilization went through three industrial revolutions, while according to the opinion of the world's leading economists, the fourth industrial revolution is ongoing, the one popularly called the Industry 4.0. Each of these industrial revolutions was characterised by technological innovations that had a key impact on the development of the entire mankind. What is characteristic of the Industry 4.0 is that it already affects all business activities, in different ways, while simultaneously developing digital and other technologies, but also affecting the entire global lifestyle. After the process of globalization and intertwining of the world into one global market, which resulted in an unobstructed expansion of business, a new era began, which may be called the age of digital transformation. The basic characteristic of the new, digital age is that it takes on new dimensions and new forms, with each passing day. Accelerated technological development, the expansion of smart devices, and the mass production of mobile devices, as some of the elements of the fourth industrial revolution, have challenged financial institutions, which have responded with digitalisation, the creation of new communicative channels towards clients, as well as with a variety of other innovative services (Šehović, 2017, 136).

Although banks are less likely to accept changes due to their structure, line of business and other characteristic, they have largely adjusted their business to the changes in the business environment and, consequently, adopted and implemented certain processes imposed by the digitalisation process. The continuous process of creating new banking products and services which are directly linked to the digitalisation process, is a clear sign that the banking sector has seriously acknowledged the upcoming changes, which certainly result in the creation of a competitive advantage and a better position in the market. According to experts, technological innovations and clients will "set new rules of the game" in the banking sector (Ćukić, 2013), which will significantly affect banks, especially the ones in which traditional banking is prominent (Tornjanski,
V., Petrović, D., \& Milanović, M., 2016). In order for banks to retain their competitiveness, growth and development, and to continually create valuable products for banking service users, as well as shareholders, bank management should without any delays acknowledge these trends and redefine existing business strategies (Fasnacht, 2009; Huo \& Hong, 2013; Tornjanski et.al., 2014) and develop new models for the expansion of knowledge.

Research so far indicates that financial institutions and the population largely benefit from the process of digitalisation and innovations (Laursen \& Salter, 2006; Fasnacht, 2009). On the other hand, despite the digitalisation representing an important step in the application of innovations, there is not enough research on these processes in the existing body of scientific research, i.e. on how digitalisation, innovations and information and communication technologies contribute to the performances of open innovations in banking (Tornjanski et al., 2016). Bearing that in mind, this paper aims at deepening and expanding the body of research on the effects of digitalisation and innovations in the financial market and the population, along with indicating the significance of these processes.

The first research hypothesis reads: "Technology and innovations do not affect the FD index."

The second research hypothesis reads: "Technology and innovations do not affect the HDI."

The third research hypothesis reads: "Technology and innovations do not affect GDP per capita."

\section{Previous Research}

Industry 4.0 or the so-called fourth industrial revolution, i.e. industry digitalisation, has for a few years been the key topic explored in order to find answers to how economies can be more competitive in global markets (Mekinjić, 2019).

The essence of industry 4.0 is in a new approach, i.e. intertwining smart digital devices and products, tools, robots and people, while its basic objective are smart factories able to adjust and efficiently integrate clients and business partners into a unique process (Mekinjić, 2019). 
odgovor kako da njihove ekonomije ojačaju globalnu konkurentnost. Prema istraživanjima koje je provela Evropska bankarska federacija (EBF, 2018) vjeruje se da će jedinstveno digitalno tržište pospješiti razvoj preduzeća koja posluju u ovom sistemu i služiće za dobrobit svih klijenata, daljeg ekonomskog rasta i daljeg zapošljavanja. Dakle, četvrta industrijska revolucija donijela je temeljite i suštinske promjene i rezultirala je potpuno novom ekonomijom - digitalnom ekonomijom (Lazarević, Đuričković 2018, 27).

Postoje tri glavne komponente digitalne ekonomije, i to (Lazarević, Đuričković 2018, 27):

- e-biznis infrastruktura (hardver, softver, telekomunikacione sisteme, mreže, ljudski kapital i sl.);

- e-biznis (fokus na to kako je realizovan/ obavljen posao, tj. bilo koji posao koji organizacija obavlja preko računara posredstvom mreže);

- e-trgovina (transfer robe, npr. kada se knjiga prodaje na mreži).

Istovremeno, OECD pod digitalnom ekonomijom podrazumijeva „zajednički naziv za opis tržišta fokusiranih na digitalnu tehnologiju“. Ona uključuje trgovinu informacionim dobrima ili uslugama putem elektronske trgovine. To funkcioniše na slojevitim osnovama sa odvojenim segmentima za transport podataka i aplikacija.

Rezultati dosadašnjih istraživanja ukazuju na potrebu uvođenja koncepta otvorenih inovacija u bankarskom sektoru, odnosno na adekvatno inkorporiranje eksternog znanja u inovacione procese pomoću odgovarajućih tehnologija (Tornjanski, Petrović, \& Milanović, 2016). U skladu sa tim, uloga banaka u ovoj tranformaciji jeste da ne budu samo inovativni partneri koji ulažu $\mathrm{u}$ inovativne finansijske tehnologije, nego da doprinesu ekonomskom rastu i razvoju na cjelokupnom finansijskom tržištu (Mekinjić, 2019).

Istovremeno, veliki broj autora se bavio procjenom uticaja finansijskog razvoja na ekonomski rast, nejednakost i ekonomsku stabilnost (Levine, 2005, Demirgüç-Kunt i Levine, 2009, i Dabla-Norris i Srivisal, 2013). Naime, finansijski sektori su se razvili širom svijeta i moderni finansijski sistemi su postali isprepleteni višedimenzionalnim procesima.
Na primjer, dok su banke i dalje obično najveće i najvažnije na tržištu postoje i investicione banke, osiguravajuća društva, investicioni fondovi, penzioni fondovi, kompanije za ulaganje u rizični kapital i mnoge druge vrste nebankarskih finansijskih institucija koje dobijaju značajnu ulogu na finansijskom tržištu. S tim u vezi, finansijska tržišta su se razvila na načine koji omogućavaju pojedincima i firmama da diversifikuju svoju štednju, a kompanije mogu prikupljati novac putem akcija, obveznica i finansijskih derivata, zaobilazeći tradicionalna bankarska kreditiranja. Konstelacija takvih finansijskih institucija i tržišta olakšava pružanje finansijskih usluga. Osim toga, važna karakteristika finansijskih sistema je njihov pristup i efikasnost. Veliki finansijski sistemi imaju ograničenu upotrebu ako nisu dostupni dovoljno velikom broju stanovništva i firmi. Čak i ako su finansijski sistemi značajni i imaju širok doseg, njihov doprinos ekonomskom razvoju bio bi ograničen ako bi bili rasipni i neefikasni. Ovaj argument su izneli, na primjer, Čihak i dr. (2012) i Aizenman, Jinjarak i Park (2015). Prema tome, raznolikost finansijskih sistema u različitim zemljama podrazumijeva da je potrebno sagledati višestruke pokazatelje za mjerenje finansijskog razvoja. Na primjer, Grujić (2019) je istraživao uticaj strukture penzijskih fondova na razvijenost finansijskih tržišta po zemljama i pokazao da različite strukure penzionih fondova mogu da utiču na razvoj finansijskog tržišta.

Upravo odatle proizilazi cilj ovog istraživanja. Cilj je da se utvrdi da li je „kopiranjem” određene zemlje po nivou digitalizacije i inovacija moguće dodatno razviti finansijsko tržište, uticati na nivo ljudskog razvoja ili na povećanje BDP-a po glavi stanovnika. S tim u vezi, pod terminom "tržište u razvoju" podrazumijevamo zemlje koje odlikuju institucionalne turbulencije, nizak nivo korporativnog upravljanja i ekonomskog razvoja u odnosu na razvijene zemlje. Hoskisson i saradnici kao zemlje u tranziciji izdvajaju sve zemlje Zapadnog Balkana (Hoskisson et al. 2000, 249-267). Ilustracije radi, institucionalno naslijeđe komunizma na tim tržištima ogleda se kroz veliku, nedisciplinovanu i neefikasnu administraciju, birokratizovan pristup institucija i korupciju (Haramija i Njavro, 
In this way, productivity and efficiency would increase and secure competitiveness in the global market.One of the interesting aspects of this revolution is that it was scheduled in advance, i.e. out of necessity due to the crisis, recession and slowdown of economic activities, which led leading countries in the European Union to search for a solution to strengthen their economies and global competitiveness. According to research conducted by the European Banking Federation (EBF, 2018), it is believed that a unique digital market will improve the development of companies performing business in this system and that it will be beneficial for all clients, further economic growth and further employment. Therefore, the fourth industrial revolution has brought thorough and essential changes and it has resulted in a completely new economics digital economics (Lazarević, Đuričković 2018, 27).

There are three main components of digital economics (Lazarević, Đuričković 2018, 27):

- e-business infrastructure (hardware, software, telecoms, networks, human capital, etc.);

- e-business (a focus on how business is realised, i.e. any business performed by the organisation on a computer through a network);

- e-trade (transfer of goods, i.e. a book being sold online).

At the same time, OECD considers digital economics "an umbrella term for the description of markets focused on digital technology". It includes trade in information goods or services through electronic trade. It functions through a layered foundation with separate segments for the transport of data and applications.

The results of existing research indicate the need for introducing the concept of openended innovations in the banking sector, i.e. adequate incorporation of external knowledge into innovation processes through suitable technologies (Tornjanski, Petrović, \& Milanović, 2016). In accordance with that, the role of banks in this transformation is not only to be innovative partners investing in innovative financial technologies, but also to contribute to the economic growth and development in the overall financial market (Mekinjić, 2019).
At the same time, a large number of authors were concerned with the evaluation of the impact of financial development on economic growth, inequality and economic stability (Levine, 2005, Demirgüç-Kunt \& Levine, 2009, Dabla-Norris \& Srivisal, 2013). Namely, financial sectors have developed across the world and modern financial systems have become permeated with multidimensional processes. For example, while banks are still usually the biggest and most important in the market, there are also investment banks, insurance companies, investment funds, pension funds, venture capital firms and many other non-bank financial institutions which are gaining an important role in the financial market. As a consequence of that, financial markets have developed in ways which enable individuals and companies to diversify their savings, while companies can collect money through shares, bonds and financial derivatives, circumventing traditional banking credit. The constellation of such financial institutions and markets simplifies the provision of such financial services. Besides that, an important characteristic of financial systems is their accessibility and efficiency. Large financial systems have a limited use if they are not accessible to a large enough number of population and companies. Even if financial systems are significant and have a wide scope, their contribution to economic development would be limited if they were wasteful and inefficient. This argument was presented, for example, in Čihak et al. (2012) and Aizenman, Jijarak \& Park (2015). Therefore, the diversity of financial systems in different countries means that it is necessary to look at multiple indicators in order to measure financial development. For example, Grujić (2019) explored the impact of pension fund structure on the development of financial markets across countries and showed that different pension fund structures can affect the development of financial markets.

That is precisely where the objective of this research originates. The goal is to determine whether it is possible to further develop the financial market or influence the level of human development or the increase in GDP per capita, by imitating a certain country in the level of digitalisation and innovations. In relation to that, the term "developing market" includes countries 
2016). Naime „birokratizovana i restriktivna vlast otvorila je put korupciji i mitu državnih službenika jer se većini građana činilo da je to jedini put do ostvarenja željenog cilja" (Dimitrova-Grajzl i Simon 2010, 206). Već i letimičan pregled zavoda za statistiku zemalja Zapadnog Balkana potvrđuje nastavak takve prakse odnosno rast zaposlenih oblastima koje se finansiraju iz budžeta: $u$ administraciji, javnoj upravi, obrazovanju i umjetnosti. S druge spoljnotrgovinskog deficita i niske stope BDP-a" (Duvnjak, 2018, 198). U BiH postoji niz socijalnoekonomskih pitanja koja još nisu riješena, a čije unapređenje podrazumijeva složena i zahtjevna rješenja (Amidžić et al. 2016, 57).

Indeks humanog razvoja je izabran kao zavisna varijabla jer on predstavlja rezultat traganja za jednom zajedničkom mjerom ekonomskog i socijalnog razvoja. Ovaj indeks je doprinos kvantifikaciji cjelokupnog

Tabela 1. Sažeti pregled reformi humanog razvoja

\begin{tabular}{|l|l|c|c|l|l|l|}
\hline \multirow{2}{*}{ Dimenzija } & \multicolumn{1}{|c|}{ Pokazatelj } & Max. & Min. & \multicolumn{2}{c|}{ Pokazatelj } & \multicolumn{2}{c|}{ Max. } \\
\cline { 2 - 5 } \cline { 4 - 6 } Transformacija
\end{tabular}

Izvor: prilagođeno iz HDR 2010; posmatrani maksimum i minimum iz HDR 2011. str 168. i Fetahagić, M. (2013)

Aneks 1: Pokazatelji humanog razvoja za Bosnu i Hercegovinu

strane, očigledno je smanjenje zaposlenih $u$ prerađivačkoj industriji. Osim toga, relevantna istraživanja potvrđuju i visok nivo korupcije kao posljedicu komunističkog sistema u novim članicama EU u odnosu na „stare” članice (Transparency International 2016). Takođe, kada se posmatraju istraživanja povjerenja $u$ institucije, zemlje $u$ tranziciji su na dnu takvih listi (Bjørnskov 2007). Osim toga, u svim malim i otvorenim ekonomijama, poput država koje čine Zapadni Balkan, sposobnosti monetarne politike su ograničene brojnim faktorima (Benazić i Rami, 2016, 1039). Dakle, kritika tranzicije zasniva se na činjenici značajnog povećanja siromaštva i propadanja, uglavnom, srednjeg sloja (Cifrić 1996, 137).

Posmatrajući tržišta u razvoju zapaža se da, kao i u svim zemljama Zapadnog Balkana, tako i u Bosni i Hercegovini, neekonomski faktori u regiji igraju najvažniju ulogu u determinisanju vrijednosti trgovine između zemalja (Trivić i Klimczak 2015, 57). Ekonomska nestabilnost proizlazi iz „,čestih reformi u kojima su potpuno zanemareni ekonomski rast i društveni uticaj promjena, niskih stopa domaćih i stranih ulaganja, socioekonomskog aspekta napretka, koji se odnosi na dostignuća zemlje u pogledu temeljnih dimenzija humanog razvoja. Ovaj razvoj uključuje tri temeljne dimenzije humanog razvoja, koje se odnose na mogućnosti koje ljudi očekuju da će postići. To su sljedeće dimenzije:

- očekivani životni vijek je postignut sposobnošću da se živi dug i zdrav život;

- postignuto obrazovanje se ostvaruje $\mathrm{kroz}$ sposobnost sticanja znanja;

- postignuti životni standard se ostvaruje kroz sposobnost da se obezbijedi pristojan prihod za život.

Promjene uvedene u HDR 2010. odnose se na izbor pokazatelja dimenzije, transformaciju $\mathrm{u}$ izračunu indeksa dimenzije, kao i metoda agregacije; GNI/per capita koristi se umjesto $\mathrm{BDP} /$ per capita.

Indeks humanog razvoja predstavlja kompromis između sveobuhvatnosti i mjerljivosti (Ghislandi, Sanderson, \& Scherbov, 2019). Ovaj indeks koristi podatke vodećih svjetskih institucija, a posebna studija je provedena za procjenu prosječnih godina školovanja ${ }^{1}$. Pokazatelji su izračunati 
characterised by institutional turbulence, low level of corporative management and economic development in comparison with developed countries. Hoskisson and associates consider all the countries in Western Balkans as countries in transition (Hoskisson et al. 2000, 249-267). For illustration purposes, the institutional legacy of communism in those markets is reflected in large, undisciplined and inefficient of monetary policy is limited by numerous factors (Benazić \& Rami, 2016, 1039). Hence, the criticism of transition is based on significant increase in poverty and deterioration of mostly middle class (Cifrić 1996, 137).

By observing developing markets it may be noted that, in both countries of the Western Balkans and Bosnia and Herzegovina, noneconomic factors in the region play the most

Table 1. A Summarised Overview of Human Development Reforms

\begin{tabular}{|c|c|c|c|c|c|c|}
\hline \multirow{2}{*}{ Dimension } & \multirow{2}{*}{ Indicator } & Max. & Min. & \multirow{2}{*}{ Indicator } & Max. & Min. \\
\hline & & \multicolumn{2}{|c|}{ Transformation } & & \multicolumn{2}{|c|}{ Transformation } \\
\hline $\begin{array}{l}\text { A long and } \\
\text { healthy life }\end{array}$ & Expected lifespan & 85 & 25 & Expected lifespan & $\begin{array}{l}83.4 \text { (Japan, } \\
\text { 2011) }\end{array}$ & 20 \\
\hline \multirow[b]{2}{*}{ Knowledge } & $\begin{array}{l}\text { Literacy rate in } \\
\text { adults }\end{array}$ & 100 & 0 & $\begin{array}{l}\text { Expected years of } \\
\text { schooling }\end{array}$ & $\begin{array}{l}18 \text { (limited to } \\
\text { maximum) }\end{array}$ & 0 \\
\hline & $\begin{array}{l}\text { Combined gross } \\
\text { ratio of enrolment in } \\
\text { schools }\end{array}$ & 100 & 0 & $\begin{array}{l}\text { Combined gross } \\
\text { ration of enrolment } \\
\text { in schools }\end{array}$ & $\begin{array}{l}13.1 \text { (Czech } \\
\text { Republic, 2005) }\end{array}$ & 0 \\
\hline $\begin{array}{l}\text { Decent standard } \\
\text { of living }\end{array}$ & $\begin{array}{l}\text { GDP/per capita (PPP } \\
\text { US\$) }\end{array}$ & 40000 & 100 & $\begin{array}{l}\text { GDP/per capita (PPP } \\
\text { US\$) }\end{array}$ & $\begin{array}{l}\text { 107,721 (Qatar, } \\
\text { 2011) }\end{array}$ & 100 \\
\hline $\begin{array}{l}\text { Aggregation } \\
\text { methods }\end{array}$ & \multicolumn{3}{|c|}{ Arithmetic mean } & \multicolumn{3}{|c|}{ Arithmetic mean } \\
\hline
\end{tabular}

Source: adapted from HDR 2010; observed minimum and maximum from HDR 2011, p. 168, and Fetahagić, M. (2013)

Supplement 1: Indicators of Human Development for Bosnia and Herzegovina

administration, bureaucratic approach by institutions, as well as in corruption (Haramija \& Njavro, 2016). Namely, "bureaucratic and restrictive governance enabled corruption and bribery of public officials because most citizens saw that as the only way of achieving the desired goal" (Dimitrova-Grajzl \& Simon 2010, 206). Even a brief insight by bureaus of statistics in countries in Western Balkans confirms the continuation of such practice, i.e. an increase in the number of employees in budget financed fields: administration, public administration, education and art. On the other hand, it is obvious that there are fewer employees in the processing industry. Besides, relevant research also confirms a high level of corruption, as a consequence of the communist system, in new member states of the EU in comparison with the "old" member states (Transparency International 2016). In addition, when one observes research on the trust in institutions, countries in transition are at the bottom of such lists (Bjørnskov 2007). Besides, in all small and open-ended economies, such as in states constituting the Western Balkans, the capacity important role in determining the amount of trade between countries (Trivić \& Klimczak 2015, 57). Economic instability is a consequence of "frequent reforms which completely disregard economic growth and the social impact of changes, low rates of domestic and foreign investments, foreign-trade deficit and low rate of GDP" (Duvnjak, 2018, 198). In $\mathrm{BiH}$ there is a number of social and economic issues which have still not been resolved, the improvement of which entails complex and demanding solutions (Amidžić et al. 2016, 57).

The human development index was chosen as a dependent variable because it represents the result of searching for a single common measure of economic and social development. This index is a contribution to the qualification of the overall socioeconomic aspect of progress, related to a country's accomplishments in relation to core dimensions of human development. This development includes three core dimensions of human development, related to possibilities which people expect to realise. Those are the following dimensions:

- the expected lifespan is achieved through 
korištenjem nove metodologije za 2010. godinu, kao i metodologije iz 1980. To je osiguralo poređenje podataka između zemalja, kao i praćenje trendova.

Veliki broj autora se bavio procjenom uticaja finansijskog razvoja na ekonomski rast, nejednakost i ekonomsku stabilnost (Levine, 2005, Demirgüç-Kunt i Levine, 2009, i Dabla-Norris i Srivisal, 2013). Finansijski razvoj uključuje poboljšanja u funkcijama koje obezbjeđuju finansijski sistemi kao: (i) udruživanje štednje; (ii) izdvajanje kapitala za produktivne investicije; (iii) praćenje tih investicija; (iv) diversifikaciju rizika $\mathrm{i}$ (v) razmjena dobara i usluga (Levine, 2005). Svaka od ovih finansijskih funkcija može uticati na odluke o štednji i investicijama i na efikasnost raspodjele sredstava. Kao rezultat toga, finansije utiču na akumulaciju kapitala i ukupnu faktorsku produktivnost, tj. na tri faktora koji određuju ekonomski rast. U mjeri u kojoj finansijski razvoj smanjuje asimetrije informacija i finansijska ograničenja i promoviše podjelu rizika, razvoj može povećati sposobnost finansijskih sistema da apsorbuju šokove i smanje pojačavanje ciklusa kroz finansijski akcelerator (Bernanke, Gertler i Gilchrist 1999), takođe $\mathrm{u}$ odnosu sa BDP-om. Na primjer, $\mathrm{u}$ uticajnoj studiji na industrijskom nivou Rajan i Zingales (1998) koriste obje mjere kako bi pokazali da viši finansijski razvoj olakšava ekonomski rast. Na strani makroekonomske volatilnosti, Dabla-Norris i Srivisal (2013) smatraju da finansijski razvoj, mjeren privatnim kreditima prema BDP-u banaka i drugih finansijskih institucija, igra značajnu ulogu u ublažavanju nestabilnosti proizvodnje, potrošnje i rasta investicija, ali samo do određene tačke. Većina istraživača u ovoj oblasti koristi varijacije ovih mjera da ispita ulogu finansijskog sistema u ekonomskom razvoju.

Da bi se prevazišli nedostaci pojedinih indikatora kao zamjena za finansijski razvoj, kreirano je mnoštvo indeksa koji pokazuju kako su razvijene finansijske institucije i finansijska tržišta u smislu njihove dubine, pristupa $i$ efikasnosti, što kulminira konačnim indeksom finansijskog razvoja (ilustracija 1). Ovaj indeks je prvobitno razvijen u kontekstu napomene MMF-a za diskusiju o osoblju „Preispitivanje finansijskog produbljivanja: stabilnost i rast na tržištima u razvoju“" (Sahay et al., 2015). Podindeksi i konačni ukupni indeks izgrađeni su za 183 zemlje na godišnjoj frekvenciji između

Ilustracija 1. Piramida indeksa finansijskog razvoja (IMF staff, bazirano na Čihák et al. 2012)

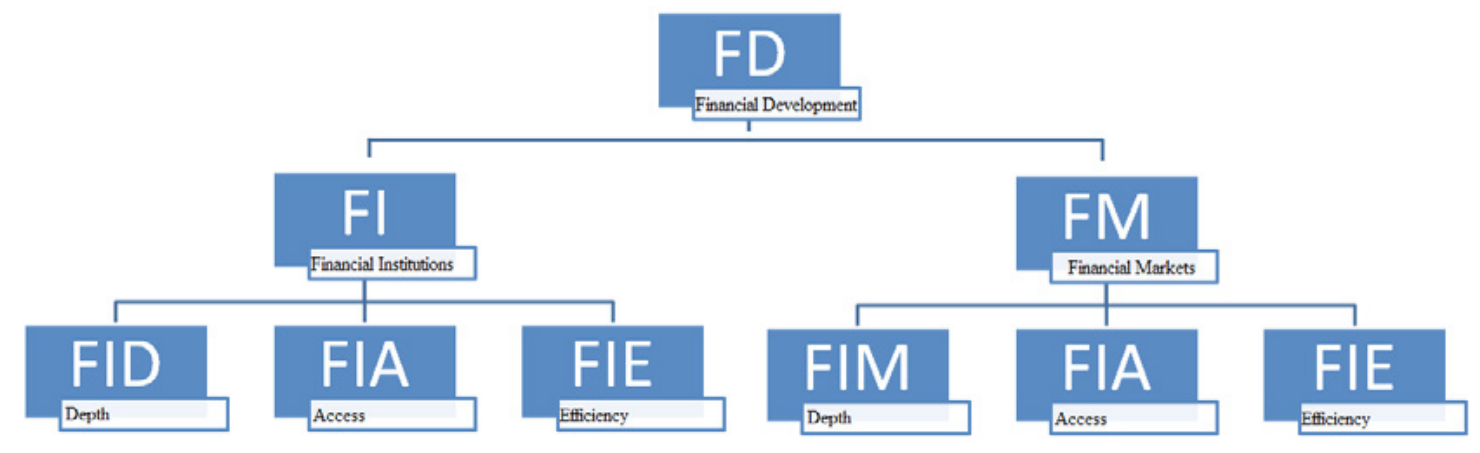

Izvor: (IMF staff, bazirano na Čihák et al. 2012)

smanjujući makroekonomsku volatilnost i nejednakost (Svirydzenka, 2016, 4).

Većina empirijske literature od sedamdesetih godina prošlog vijeka približava finansijski razvoj dvjema mjerama finansijske dubine odnosom privatnih kredita prema BDP-u i, u manjoj mjeri, kapitalizacijom tržišta akcija,
1980. i 2013. godine. Finansijski razvoj se definiše kao kombinacija dubine (veličina i likvidnost tržišta), pristupa (sposobnost pojedinaca i kompanija da pristupe finansijskim uslugama) i efikasnosti (sposobnost institucija da pružaju finansijske usluge uz niske troškove i održive prihode, i nivo aktivnosti tržišta kapitala). Ovaj

1 Izvori podataka: Life expectancy at birth: UNDESA (2009d); Average years of schooling: special study by Barro and Lee (2010) available on: http://www.nber.org/papers/w1590; Expected years of schooling: UNESCO Institute for Statistics (2010a); GNP/per capita: World Bank (2010g) i IMF (2010a). 
the ability to live a long and healthy life;

- achieved education is realised through the ability to acquire knowledge;

- the achieved standard of living is reached through the ability to obtain a decent income for life.

Changes introduced in HDR 2010 are related to the choice of dimension indicators, transformation in the calculation of the dimension index, as well as the aggregation method: GNI/per capita is used instead of GDP/ per capita.

The human development index presents a compromise between inclusion and comparability (Ghislandi, Sanderson \& Scherbov, 2019). This index uses data from the world's leading institutions, and a special study was conducted for the evaluation of average number of years of schooling ${ }^{1}$. The indicators were calculated by using new methodology for 2010, as well as methodology from 1980. That enabled the comparison of data between countries, as well as the monitoring of trends.

A large number of authors dealt with the evaluation of theimpact of financial development on economic growth, inequality and economic instability (Levine, 2005, Demirgüç-Kunt \& Levine, 2009, and Dabla-Norris \& Srivisal, 2013). Financial development includes improvements
Each of these financial functions can affect decisions on savings and investments and the efficiency of allocation of assets. As a result, finances affect the accumulation of capital and the total factor productivity, i.e. the three factors determining economic growth. To the extent that financial development diminishes the asymmetries of information and financial limitation and promotes the distribution of risk, development may increase the capacity of financial systems to absorb shock and diminish the amplification of cycles through a financial accelerator (Bernanke, Gertler \& Gilchrist 1999), while diminishing macroeconomic volatility and inequality (Svirydzenka, 2016, 4).

Most empirical literature from the seventies relates financial development with the two measures of financial depth - ratio of private credit to GDP and, to a lesser extent, the ratio of the capitalisation of the shares market, also to GDP. For instance, in an influential study at an industrial level Rajan \& Zingales (1998) use both measures to show that a higher degree of financial development facilitates economic growth. As for macroeconomic volatility, DablaNorris \& Srivisal (2013) consider that financial development, measured through private credit against GDP of banks and other financial institutions, plays a significant role in mitigating

Illustration 1. Pyramid of Indices of Financial Development (IMF staff, based on Čihák et al. 2012)

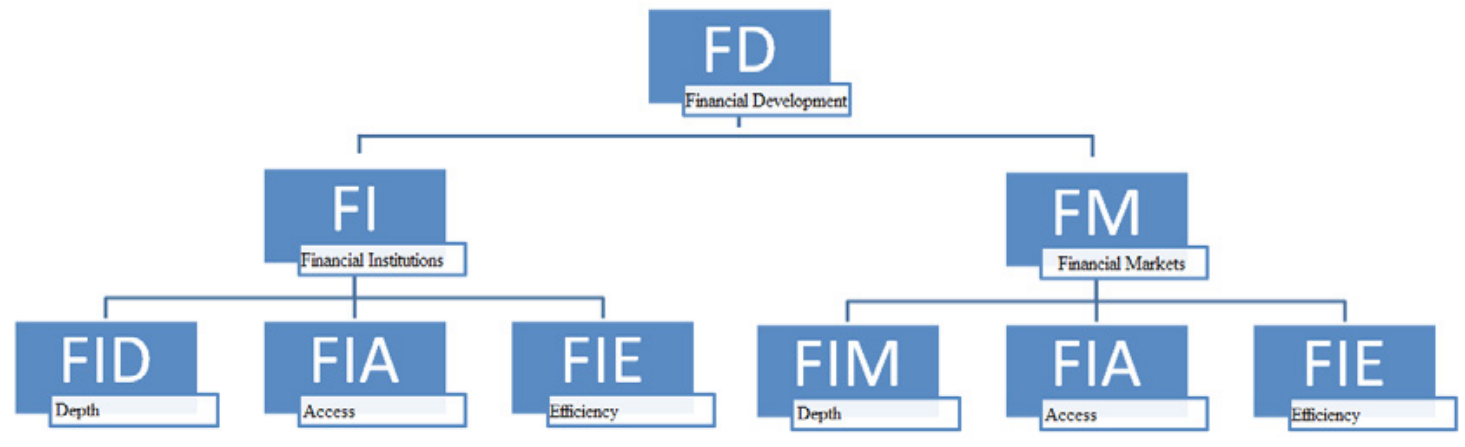

Source: (IMF staff, based on Čihák et al. 2012)

in functions secured by financial systems, such as: (i) pooling of savings; (ii) allocating capital to productive investments; (iii) tracking those investments; (iv) diversification of risk; (v) exchange of goods and services (Levine, 2005). the instability of production, consumption and investment growth, but only to a certain extent. Most researchers in this field use variations of these measures to examine the role of the financial system in economic development.

1 Sources of data: Life expectancy at birth: UNDESA (2009d); Average years of schooling: special study by Barro and Lee (2010) available on: http://www.nber.org/papers/w1590; Expected years of schooling: UNESCO Institute for Statistics (2010a); GNP/per capita: World Bank (2010g) and IMF (2010a). 
široki multidimenzionalni pristup definisanju finansijskog razvoja prati matricu karakteristika finansijskog sistema koju je razvio Čihák sa saradnicima. (2012).

Imajući u vidu bogatstvo informacija o svojstvima finansijskog sistema - postoji 105 različitih indikatora u GFDD i 46 indikatora u FinStats - nije moguće pratiti sve ove različite pokazatelje pojedinačno, posebno $\mathrm{u}$ empirijskom radu. Čak i da je to bilo moguće, nijedan pojedinačni indikator, kada bi se koristio sam, ne bi pružio sveobuhvatno razumijevanje nivoa finansijskog razvoja. Podindeksi i konačni indeks povezuju ove različite pokazatelje i omogućavaju sveobuhvatnu procjenu pojedinih karakteristika finansijskih sistema i ukupnog nivoa finansijskog razvoja. Kao rezultat toga, indeksi dozvoljavaju da se utvrdi gdje su nedostaci u finansijskom razvoju nedoslijedni ili koji aspekti finansijskog razvoja utiču na makroekonomske rezultate, koji bi zatim mogli biti detaljnije istraženi koristeći raščlanjene podatke od FinStats ili GFDD.

U nastavku rada opisana metodologija je korištena za konstrukciju indeksa, uključujući izvore podataka, tretman nedostajućih vrijednosti, funkcionalnu formu i težine koje se koriste $\mathrm{u}$ agregaciji. On pokazuje kako se novi indeksi upoređuju sa tradicionalnim mjerama i ključnim stilizovanim činjenicama o finansijskom razvoju širom svijeta. U diskusiji ćemo se osvrnuti na neka ograničenja i nedostatke indeksa, s ciljem da pokažemo u kojoj mjeri struktura i veličina penzijskih fondova utiču na rezultat indeksa. Cilj je da utvrdimo da li je „kopiranjem” određene zemlje po strukturi i veličini indeksa moguće dodatno razviti finansijsko tržište. S tim u vezi kao termin "tržište u razvoju” podrazumijevamo zemlje koje odlikuju institucionalne turbulencije, nizak nivo korporativnog upravljanja i ekonomskog razvoja u odnosu na razvijene zemlje. Hoskisson i saradnici kao zemlje u tranziciji izvdajaju sve zemlje Zapadnog Balkana (Hoskisson et al. 2000, 249-267). Ilustracije radi, institucionalno nasljeđe komunizma na tim tržištima ogleda se kroz veliku, nedisciplinovanu i neefikasnu administraciju, birokratizovan pristup institucija i korupciju (Haramija i Njavro, 2016). Naime „birokratizovana i restriktivna vlast otvorila je put korupciji i mitu državnih službenika jer se većini građana činilo da je to jedini put do ostvarenja željenog cilja" (Dimitrova-Grajzl i Simon 2010, 206). Već i letimičan pregled zavoda za statistiku zemalja Zapadnog Balkana potvrđuje nastavak takve prakse, odnosno rast zaposlenih u oblastima koje se finansiraju iz budžeta: $u$ administraciji, javnoj upravi, obrazovanju i umjetnosti. $S$ druge strane, očigledno je smanjenje zaposlenih u prerađivačkoj industriji. Osim toga, relevantna istraživanja potvrđuju i visok nivo korupcije kao posljedicu komunističkog sistema u novim članicama EU u odnosu na "stare” članice. Takođe, kada se posmatraju istraživanja povjerenja $\mathrm{u}$ institucije, zemlje $\mathrm{u}$ tranziciji su na dnu takvih listi (Bjørnskov 2007). Osim toga, u svim malim i otvorenim ekonomijama, poput država koje čine Zapadni Balkan, sposobnosti monetarne politike su ograničene brojnim faktorima (Benazić i Rami, 2016, 1039). Dakle, kritika tranzicije zasniva se na činjenici značajnog povećanja siromaštva i propadanja, uglavnom, srednjeg sloja (Cifrić 1996, 137).

\section{Podaci}

Podatke o nivou tehnološkog razvoja i inovacija smo preuzeli iz

Tabela 2. Tabela-matrica međusobne korelacije sve četiri posmatrane promenljive (svaka sa svakom od zemalja OECD-a)

\begin{tabular}{|l|c|c|c|c|}
\hline \multicolumn{1}{|c|}{ Opis } & $\begin{array}{c}\text { Skala po } \\
\text { tehnologiji i } \\
\text { inovacijama }\end{array}$ & FD Indeks & HD Indeks & $\begin{array}{c}\text { BDP per } \\
\text { capita }\end{array}$ \\
\hline $\begin{array}{l}\text { Skala po } \\
\text { tehnologiji i } \\
\text { inovacijama }\end{array}$ & 1,00 & 0,37 & 0,72 & 0,44 \\
\hline FD Indeks & 0,37 & 1,00 & 0,48 & 0,50 \\
\hline HD Indeks & 0,72 & 0,48 & 1,00 & 0,76 \\
\hline BDP per capita & 0,44 & 0,50 & 0,76 & 1,00 \\
\hline
\end{tabular}

Izvor: Kalkulacija autora publikacije Readiness for the Future of Production Report 2018, podatke za razvijenost tržišta iskazivali smo uz pomoć FD indeksa, a nivo indeksa humanog razvoja smo koristili iz podataka koje daje United Nations Development Programme. Osim toga, u radu smo 
In order to overcome the shortcomings of specific indicators as a replacement for financial development, a variety of indices have been created which indicate the level of development of financial institutions and markets regarding their depth, accessibility and efficiency, which culminates in the financial development index (illustration 1). This index was initially developed in the context of a remark by the IMF on the staff discussion note "Rethinking Financial Deepening: Stability and Growth in Emerging Markets" (Sahay et al., 2015). Subindices and the final total index were constructed for 183 countries at an annual frequency between 1980 and 2013. Financial development is defined as a combination of depth (market size and liquidity), accessibility (the ability of individuals and companies to access financial services) and efficiency (the ability of institutions to provide financial services at a low cost and sustainable income, as well as the level of activity in the capital market). This broad multidimensional approach to defining financial development follows the matrix of the features of financial system developed by Čihák et al. (2012).

Bearing in mind the wealth of information on the features of the financial system - there are 105 different indicators in GFDD and 46 indicators in FinStats - it is not possible to follow all these different indicators individually, especially in empirical work. Even if that were possible, no individual indicator, if used on its own, would provide a thorough understanding of the level of financial development. Sub-indices and the final index connect these different indicators and enable a thorough estimate of specific features of the financial system and the overall level of financial development. As a result, indices enable the determination of aspects in which flaws in financial development are inconsistent or aspects of financial development which affect macroeconomic results, which could in turn be explored in more detail by using the divided data from FinStats or GFDD.

In the remainder of the paper the described methodology is used for the construction of indices, including data sources, the treatment of missing values, functional form and weight used in aggregation. It indicates how the new indices are compared to traditional measures and key stylised facts on the financial development across the world. In the discussion we will look at some limitations and shortcomings of indices with the objective of demonstrating the extent to which the structure and size of pension funds affects the result of indices. The goal is to determine whether it is possible to further develop the financial market by imitating a certain country in terms of the structure and size of indices. Therefore, under the term "developing market" we mean countries characterised by institutional turbulence, low level of corporative management and economic development in relation to developed countries. Hoskisson and associates consider all the countries in Western Balkans as countries in transition (Hoskisson et al. 2000, 249-267). For illustration purposes, the institutional legacy of communism in those markets is reflected in large, undisciplined and inefficient administration, bureaucratic approach of institution, as well as in corruption (Haramija \& Njavro, 2016). Namely, "the bureaucratic and restrictive governance enabled corruption and the bribery of public officials because most citizens saw that as the only way of achieving the desired goal" (Dimitrova-Grajzl \& Simon 2010, 206). Even a brief insight by bureaus of statistics in countries in Western Balkans confirms the continuation of such practice, i.e. an increase in the number of employees in fields being financed from the budget: administration, public administration, education and art. On
Table 2. Table-Matrix of the Correlation of all Four Observed Variables (each country of OECD with the others)

\begin{tabular}{|l|c|c|c|c|}
\hline \multicolumn{1}{|c|}{ Description } & $\begin{array}{c}\text { Scale } \\
\text { according to } \\
\text { technology } \\
\text { and } \\
\text { innovations }\end{array}$ & FD Index & HD Index & $\begin{array}{c}\text { GDP per } \\
\text { capita }\end{array}$ \\
\hline $\begin{array}{l}\text { Scale according } \\
\text { to technology } \\
\text { and innovations }\end{array}$ & 1.00 & 0.37 & 0.72 & 0.44 \\
\hline FD Index & 0.37 & 1.00 & 0.48 & 0.50 \\
\hline HD Index & 0.72 & 0.48 & 1.00 & 0.76 \\
\hline GDP per capita & 0.44 & 0.50 & 0.76 & 1.00 \\
\hline
\end{tabular}

Source: Authors' calculation 
Tabela 3. Tabela-matrica međusobne korelacije sve četiri posmatrane promenljive (svaka sa svakom od zemalja koje nisu iz OECD-a)

\begin{tabular}{|l|c|c|c|c|}
\hline \multicolumn{1}{|c|}{ Opis } & $\begin{array}{c}\text { Skala po } \\
\text { tehnologiji i } \\
\text { inovacijama }\end{array}$ & $\begin{array}{c}\text { FD } \\
\text { Indeks }\end{array}$ & $\begin{array}{c}\text { HD } \\
\text { Indeks }\end{array}$ & $\begin{array}{c}\text { BDP per } \\
\text { capita }\end{array}$ \\
\hline $\begin{array}{l}\text { Skala po } \\
\text { tehnologiji i } \\
\text { inovacijama }\end{array}$ & 1,00 & 0,50 & 0,69 & 0,67 \\
\hline FD Indeks & 0,50 & 1,00 & 0,59 & 0,59 \\
\hline HD Indeks & 0,69 & 0,59 & 1,00 & 0,90 \\
\hline BDP per capita & 0,67 & 0,59 & 0,90 & 1,00 \\
\hline
\end{tabular}

Izvor: Kalkulacija autora

posmatrali podatke koje su dali The National Bureau of Economic Research za BDP per capita. (2019), Organizacija za ekonomsku saradnju i razvoj za FD Indeks (2019) Svjetski ekonomski forum za podatke o digitalitaciji i inovacijama (World Economic Forum 2018) i Međunarodni monetarni fond za BDP per capita (2019).

\section{Metodologija}

U radu smo posmatrali podatke koje su dali The National Bureau of Economic Research (2019), Organizacija za ekonomsku saradnju i razvoj (2019), Svjetski ekonomski forum (World Economic Forum 2018), te BDP po glavi stanovnika koji je objavio Međunarodni monetarni fond (2019). Za svaku posmatranu OECD-a zemlju smo uzeli u obzir nivo digitalizacije i uporedili smo ga sa FD indeksom, HD indeksom i BDP-om po glavi stanovnika u 2018. godini.

Vezu između ostvarenih stopa neizmirenja i makroekonomskih pokazatelja možemo proveravati na više načina. Linearnu regresiju smo koristili jer smo pretpostavili da postoji linearni odnos između nezavisne varijable $(X)$ i zavisne varijable $(\mathrm{Y})$. Hipoteze smo

Tabela 4. Regresiona analiza podataka za nivo digitalizacije i FD indeksa za zemlje

\begin{tabular}{|c|c|}
\hline \multicolumn{2}{|c|}{ Regression Statistics } \\
\hline R Square & 0,137909875 \\
\hline Adjusted R Square & 0,112554283 \\
\hline Standard Error & 0,183122067 \\
\hline Observations & 36 \\
\hline Regression coefficient & 0,047510826 \\
\hline Standard Error & 0,020371911 \\
\hline $\mathrm{F}$ & 5,439031952 \\
\hline Significance F & 0,02575015 \\
\hline F crit & 2,23977317 \\
\hline Test & $\begin{array}{r}\text { ne možemo } \\
\text { odbaciti }\end{array}$ \\
\hline
\end{tabular}

Ilustracija 2. Prikaz korelacije i determinacije digitalizacije i inovacija i FD indeksa po zemljama OECD-a

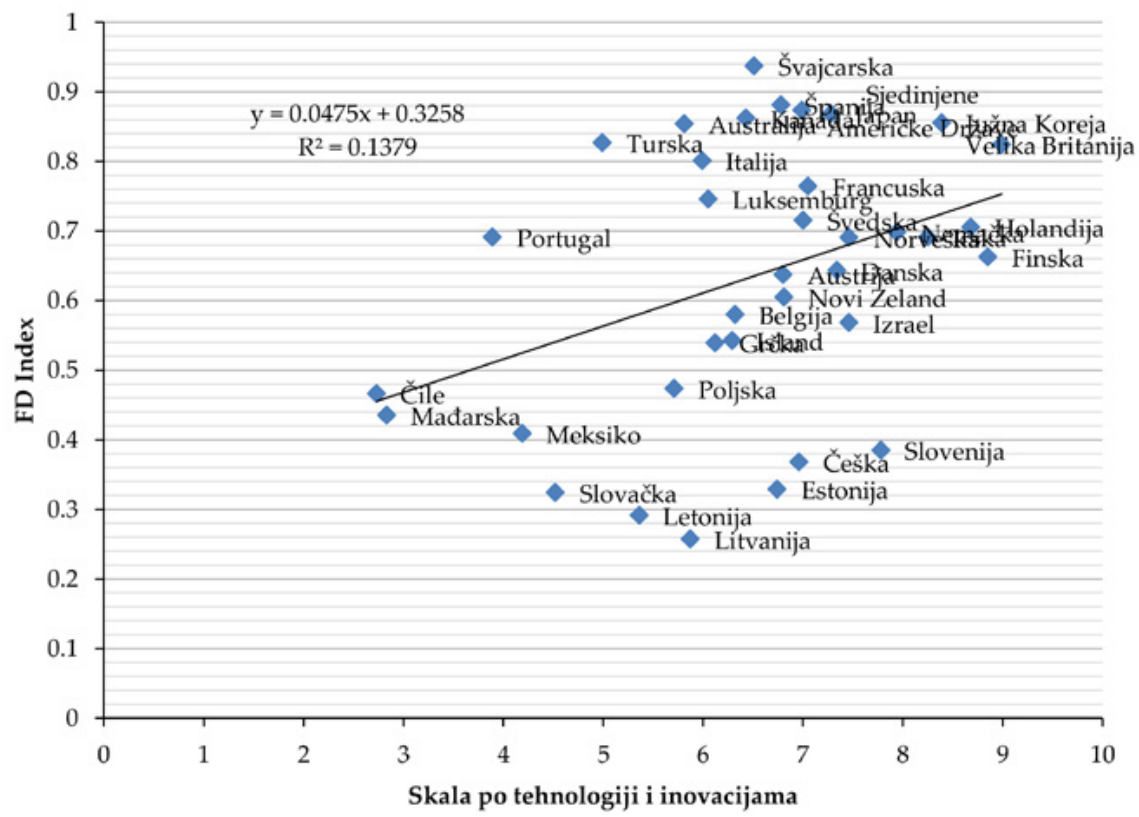

Izvor: Prikaz autora 
the other hand, it is obvious that there are fewer employees in the processing industry. Besides, relevant research also confirms a high level of corruption as a consequence of the communist system in new member states of the EU in comparison with the "old" member states. In addition, when one observes research on the trust in institutions, countries in transition are at the bottom of such lists (Bjørnskov

Table 4. Regression Analysis of Data for the Level of Digitalisation and FD Index for Countries of OECD

\begin{tabular}{|l|r|}
\hline \multicolumn{2}{|c|}{ Regression Statistics } \\
\hline R Square & 0.137909875 \\
\hline Adjusted R Square & 0.112554283 \\
\hline Standard Error & 0.183122067 \\
\hline Observations & 36 \\
\hline Regression Coefficient & 0.047510826 \\
\hline Standard Error & 0.020371911 \\
\hline F & 5.439031952 \\
\hline Significance F & 0.02575015 \\
\hline F crit & 2.23977317 \\
\hline Test & $\begin{array}{r}\text { cannot be } \\
\text { dismissed }\end{array}$ \\
\hline
\end{tabular}

2007). Besides, in all small and open-ended economies, such as in states constituting the Western Balkans, the capacity of monetary policy is limited by numerous factors (Benazić \& Rami, 2016, 1039). Hence, the criticism of transition is based on significant increase in poverty and deterioration of mostly middle class (Cifrić 1996, 137).

\section{Data}

Data on the level of technological development and innovations were taken from the publication Readiness for the Future of Production Report 2018, data on the market development were expressed through FD index, and the level of human development index was found in data from

Illustration 2. An Overview of Correlation and Determination of

Digitalisation and Innovations and FD Index by Countries in OECD

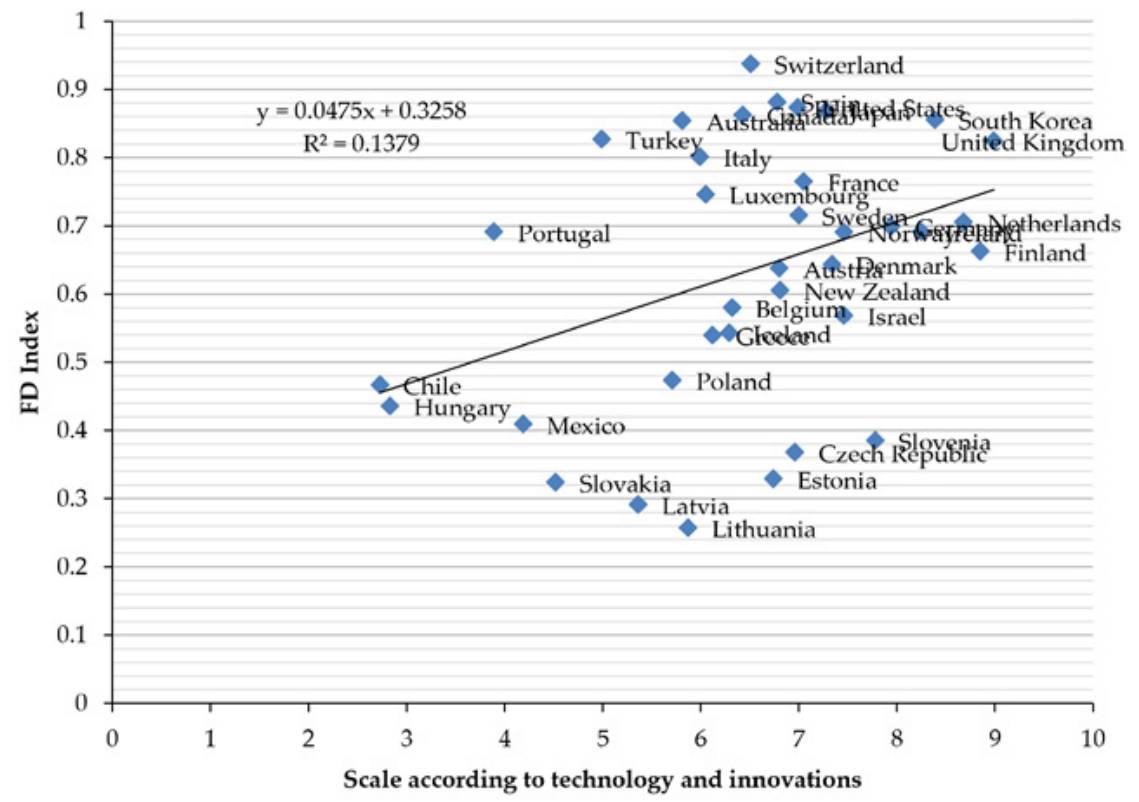


postavili kao:

$\mathrm{HO}$ - nul-hipoteza $=$ negacijska

H1 - alternativna = afirmacijska

S tim u vezi, istraživačko pitanje je postavljeno tako da se ispituje da li pojava $X$ utiče na pojavu Y. Prema tome, hipoteze su: $\mathrm{HO}_{1}$ : Tehnologije i inovacije ne utiču na FD indeks.

$\mathrm{HO}_{2}$ : Tehnologije i inovacije ne utiču na HDI.

$\mathrm{HO}_{3}$ : Tehnologije i inovacije ne utiču na BDP per capita.

\section{Rezultati}

Analizirajući odnos digitalizacije i inovacija po zemljama OECD-a i FD indeksa dobili smo tabelu 4.

$R$ kvadrat $\left(R^{2}\right)$ jednak je 0,137910. To znači
Tabela 5. Regresiona analiza podataka za nivo digitalizacije i HD indeksa za zemlje OECD-a

\begin{tabular}{|l|r|}
\hline \multicolumn{2}{|c|}{ Regression Statistics } \\
\hline R Square & 0,51194416 \\
\hline Adjusted R Square & 0,49758958 \\
\hline Standard Error & 0,03002224 \\
\hline Observations & 36 \\
\hline Regression coefficient & 0,019945743 \\
\hline Standard Error & 0,003339906 \\
\hline F & 35,66415996 \\
\hline Significance F & $9,36524 \mathrm{E}-07$ \\
\hline F crit & 2,23977317 \\
\hline Test & odbacujemo \\
\hline
\end{tabular}

Izvor: Kalkulacija autora

99\% ne možemo da odbacimo hipotezu da "tehnologije i inovacije ne utiču na FD indeks"

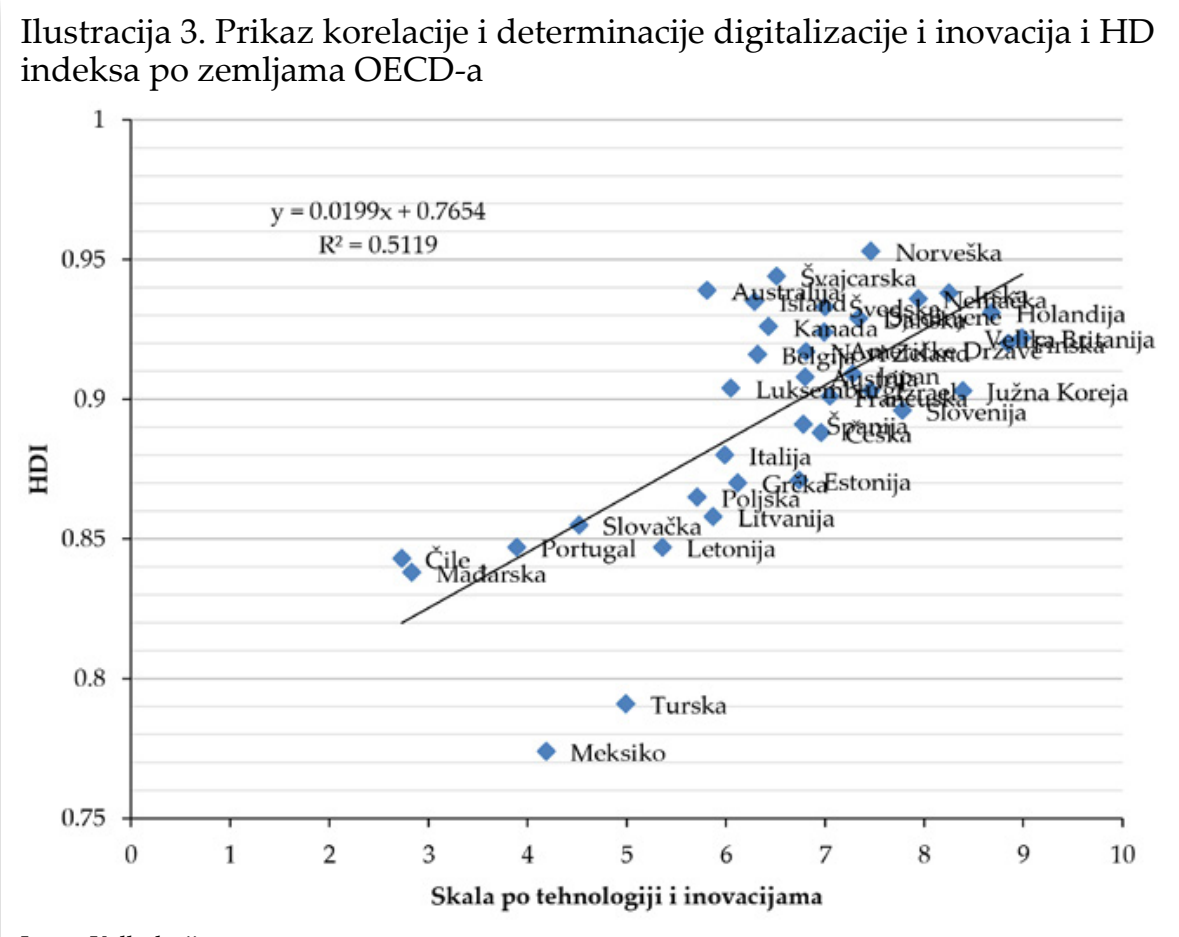

Izvor: Kalkulacija autora

da nezavisna varijabla (varijabla $X$ - nivo digitalizacije i inovacija) objašnjava $13,8 \%$ varijable Y - FD indeks. Drugim riječima, digitalizacija i inovacije utiču oko $13,9 \%$ na razvijenost finansijskog tržišta. Koeficijent višestruke korelacije (R) jednak je 0,371362188, što znači da postoji slaba direktna veza između nezavisne i zavisne varijable.

$\mathrm{S}$ obzirom na to da je $\mathrm{p}$ vrijednost od 0,02575015 veća od 0,01 , sa sigurnošću od i možemo da zaključimo da "nivoi digitalizacije $\mathrm{i}$ inovacija ne stoje $u$ statistički značajnoj vezi sa FD indeksom".

Međutim, kada posmatramo odnos digitalizacije i inovacija po zemljama OECD-a i HD indeks dobijamo tabelu 5.

$R$ kvadrat $\left(R^{2}\right)$ jednak je 0,5119 . To znači da nezavisna varijabla (varijabla $X$ - nivo digitalizacije i inovacija) objašnjava 51,2\% varijable $\mathrm{Y}-\mathrm{HD}$ indeks. Drugim riječima, 
Table 5. Regression Analysis of Data on the Level of Digitalisation and HD Index for Countries of OECD

\begin{tabular}{|l|r|}
\hline \multicolumn{2}{|c|}{ Regression Statistics } \\
\hline R Square & 0.51194416 \\
\hline Adjusted R Square & 0.49758958 \\
\hline Standard Error & 0.03002224 \\
\hline Observations & 36 \\
\hline Regression coefficient & 0.019945743 \\
\hline Standard Error & 0.003339906 \\
\hline F & 35.66415996 \\
\hline Significance F & $9.37 \mathrm{E}-07$ \\
\hline F crit & 2.23977317 \\
\hline Test & dismissed \\
\hline
\end{tabular}

Source: Authors' calculation

the United Nations Development Programme. Besides, in the paper we have observed data given by the National Bureau of Economic Research for GDP per capita (2019), Organisation for Economic Co-operation and Development for FD index (2019), The World Economic Forum for data on digitalisation and innovations (2018) and International Monetary Fund for GDP per capita (2019).
(2019), the Organisation for Economic CoOperation and Development (2019), the World Economic Forum (2018) and the International Monetary Fund for GDP per capita (2019). For each country we considered the level of digitalisation and compared it to the FD index, HD index and GDP per capita in 2018.

The relationship between the realised rates of non-payment of liabilities and macroeconomic indicators may be checked in several ways. We used linear regression because we supposed that there is a linear relationship between the independent variable $(X)$ and dependent variable $(\mathrm{Y})$.

Hypotheses were constructed in the following manner:

$\mathrm{HO}$ - null-hypothesis $0=$ negative

$\mathrm{H} 1$ - alternative $=$ affirmative

In relation to that, the research question was formulated so as to ask whether variable $X$ affects the variable $Y$. Therefore, the hypotheses are:

$\mathrm{HO}_{1}$ : Technologies and innovations do not affect the FD index.

$\mathrm{HO}_{2}$ : Technologies and innovations do not affect

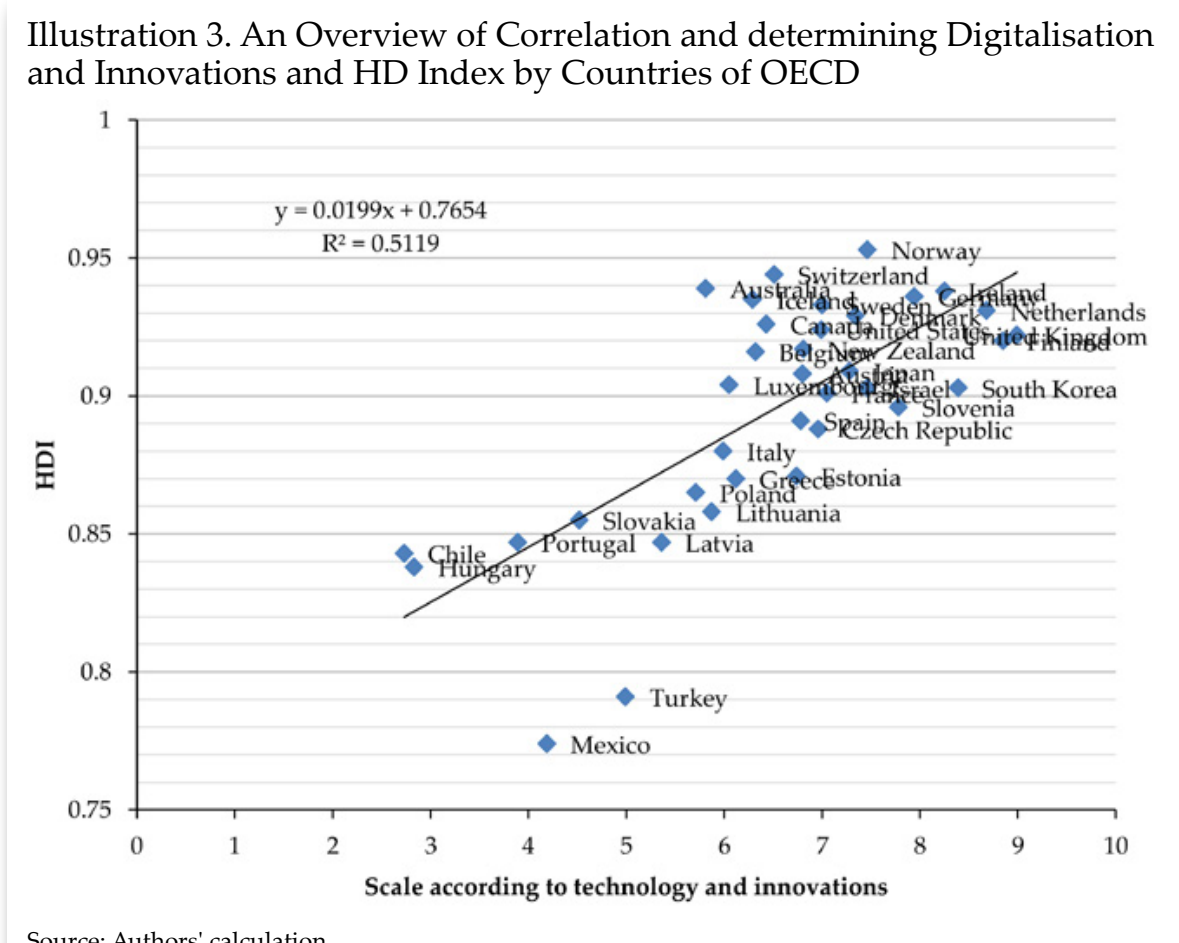

Source: Authors' calculation

\section{Methodology}

In the paper we have observed the data given by the National Bureau of Economic Research the HDI.

$\mathrm{HO}_{3}$ : Technologies and innovations do not affect GDP per capita. 
Tabela 6. Regresiona analiza podataka za nivo tehnoloških inovacija i BDP per capita

\begin{tabular}{|l|r|}
\hline \multicolumn{2}{|c|}{ Regression Statistics } \\
\hline R Square & 0,1950785 \\
\hline Adjusted R Square & 0,1714043 \\
\hline Standard Error & 21767,555 \\
\hline Observations & 36 \\
\hline Regression coefficient & 6951,3334 \\
\hline Standard Error & 2421,5908 \\
\hline F & 8,2401428 \\
\hline Significance F & 0,0070014 \\
\hline F crit & 2,2397732 \\
\hline Test & odbacujemo \\
\hline Izvor: Kalkulacija autora &
\end{tabular}

Tabela 7. Regresiona analiza podataka za nivo tehnoloških inovacija i FDI u slučajnom uzorku zemalja van OECD-a

\begin{tabular}{|l|r|}
\hline \multicolumn{2}{|c|}{ Regression Statistics } \\
\hline R Square & 0,2459 \\
\hline Adjusted R Square & 0,212237 \\
\hline Standard Error & 0,155548 \\
\hline Observations & 24 \\
\hline Regression coefficient & 0,06524 \\
\hline Standard Error & 0,024319 \\
\hline F & 7,19658 \\
\hline Significance F & 0,013597 \\
\hline F crit & 2,737849 \\
\hline Test & ne možemo odbaciti \\
\hline Izvor: Kalkulacija autora &
\end{tabular}

Ilustracija 4. Prikaz korelacije i determinacije digitalizacije i inovacija i BDP per capita po zemljama OECD-a

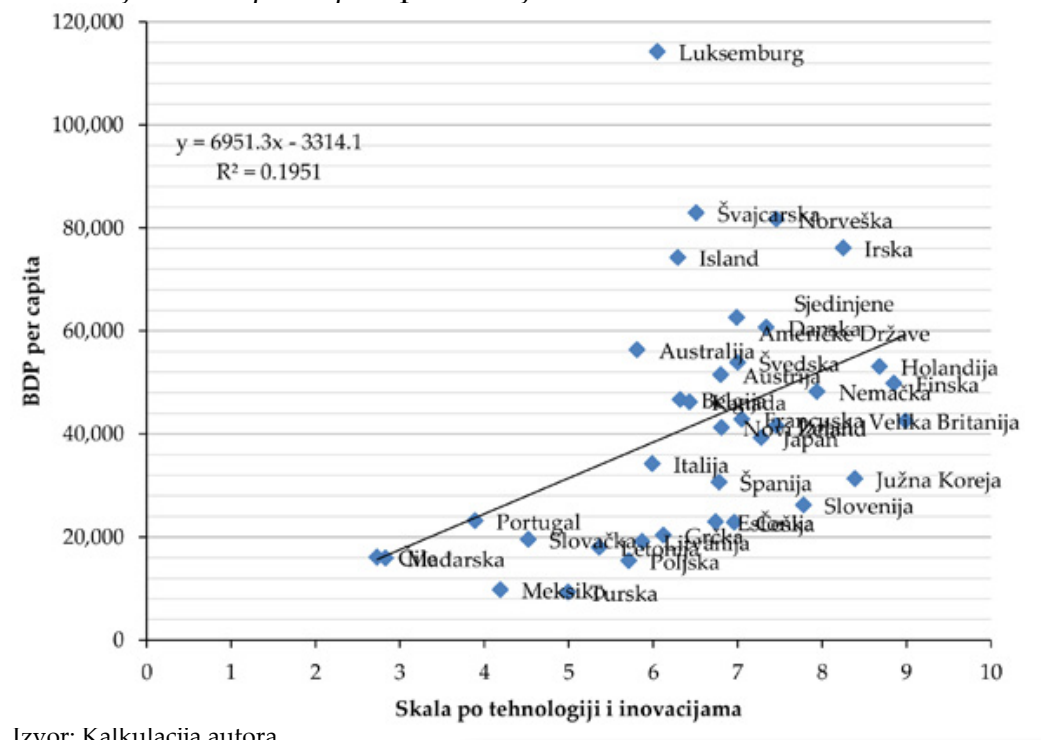

Ilustracija 5. Prikaz korelacije i determinacije digitalizacije i inovacija i FD indeksa u slučajnom uzorku zemalja van OECD-a

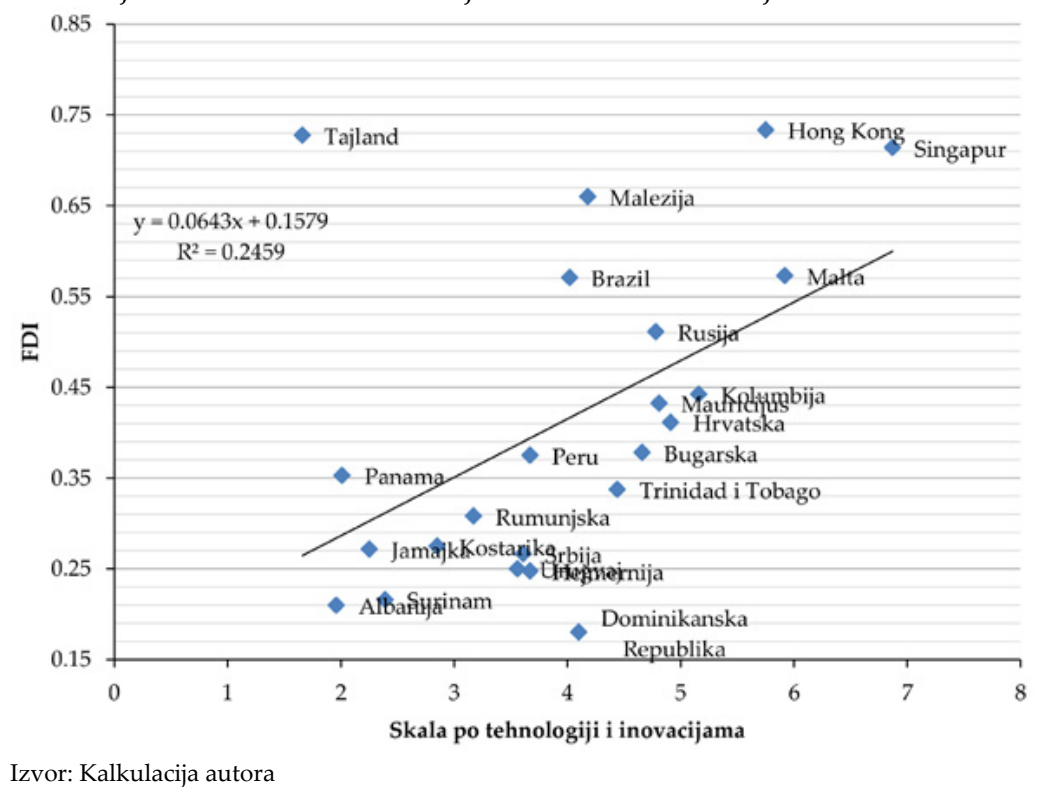


Table 6. Regression Analysis of Data for the Level of Technological Innovations and GDP Per Capita

\begin{tabular}{|l|r|}
\hline \multicolumn{2}{|c|}{ Regression Statistics } \\
\hline R Square & 0.1950785 \\
\hline Adjusted R Square & 0.1714043 \\
\hline Standard Error & 21767.555 \\
\hline Observations & 36 \\
\hline Regression coefficient & 6951.3334 \\
\hline Standard Error & 2421.5908 \\
\hline F & 8.2401428 \\
\hline Significance F & 0.0070014 \\
\hline F crit & 2.2397732 \\
\hline Test & dismissed \\
\hline
\end{tabular}

Table 7. Regression Analysis of Data on the Level of Technological Innovations and FDI in a Random Sample of Countries Outside OECD

\begin{tabular}{|l|r|}
\hline \multicolumn{2}{|c|}{ Regression Statistics } \\
\hline R Square & 0.2459 \\
\hline Adjusted R Square & 0.212237 \\
\hline Standard Error & 0.155548 \\
\hline Observations & 24 \\
\hline Regression coefficient & 0.06524 \\
\hline Standard Error & 0.024319 \\
\hline F & 7.19658 \\
\hline Significance F & 0.013597 \\
\hline F crit & 2.737849 \\
\hline Test & $\begin{array}{l}\text { cannot be } \\
\text { dismissed }\end{array}$ \\
\hline
\end{tabular}

Source: Authors' calculation

Illustration 4. An Overview of Correlation and Determination of Digitalisation and Innovations and GDP Per Capita Across Countries of OECD

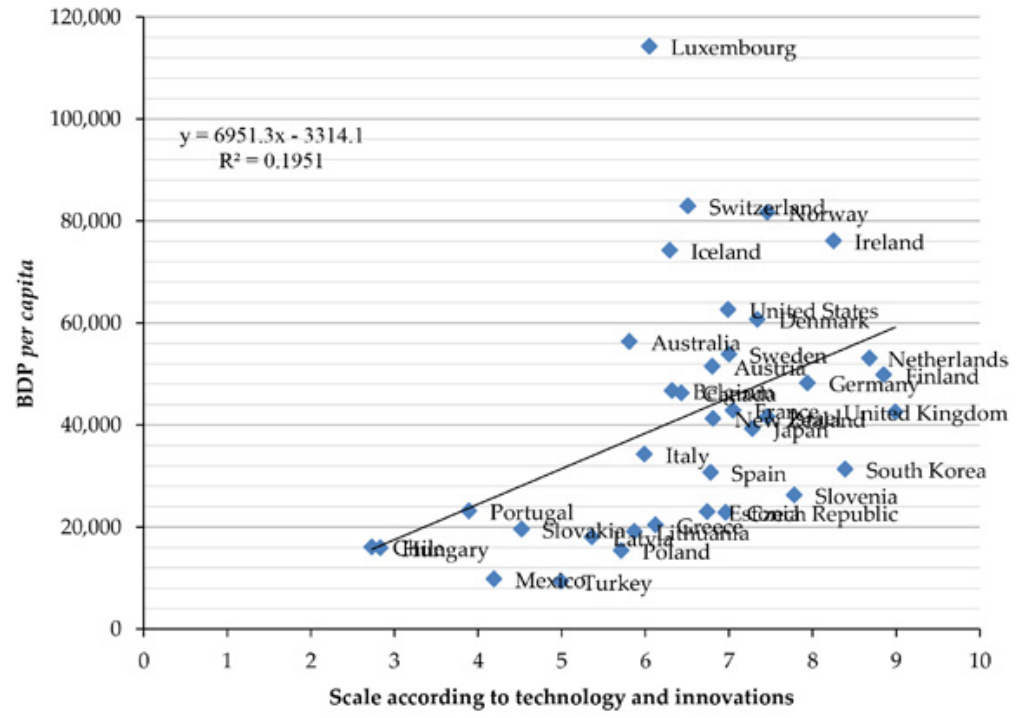

Source: Authors' calculation

Illustration 5. An Overview of Correlation and Determining

Digitalisation and Innovations and FD Index in a Random Sample of Countries Outside the OECD

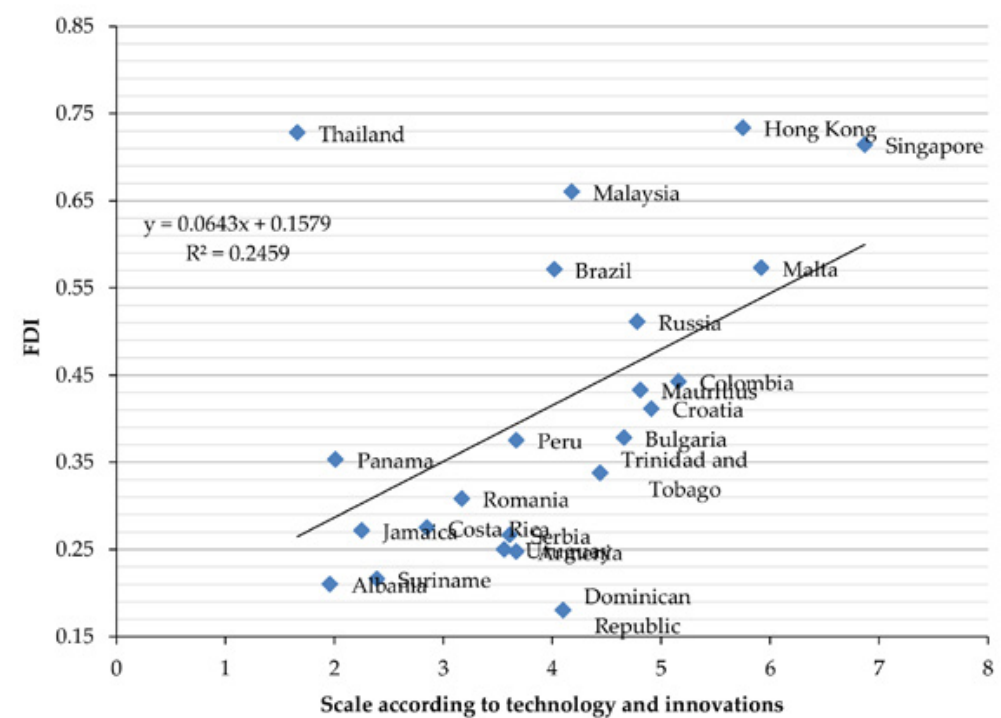


Tabela 8. Regresiona analiza podataka za nivo tehnoloških inovacija i HDI u slučajnom uzorku zemalja van OECD-a

\begin{tabular}{|l|r|}
\hline \multicolumn{2}{|c|}{ Regression Statistics } \\
\hline R Square & 0,4739 \\
\hline Adjusted R Square & 0,450583 \\
\hline Standard Error & 0,040733 \\
\hline Observations & 24 \\
\hline Regression coefficient & 0,028382 \\
\hline Standard Error & 0,006368 \\
\hline F & 19,86252 \\
\hline Significance F & 0,000198 \\
\hline F crit & 2,737849 \\
\hline Test & odbacujemo \\
\hline Izvor: Kalkulacija autora & \\
\hline
\end{tabular}

digitalizacija i inovacije utiču oko 52,2\% na nivo indeksa humanog razvoja $u$ zemlji. Koeficijent višestruke korelacije (R) jednak je razvoja, dok školovanje utiče i na BDP i na digitalizaciju. Veza sa finansijskim razvojem je manje očigledna.

$S$ obzirom na to da je $\mathrm{p}$ vrijednost 0.0000009365 značajno manja od 0,01 sa sigurnošću od 99\% možemo da odbacimo hipotezu da ,tehnologije i inovacije ne utiču na HD indeks" i da zaključimo da nivo digitalizacije $\mathrm{i}$ inovacija stoje $\mathrm{u}$ vezi sa FD indeksom pod pretpostavkom nepromjenjenih ostali varijabli.

Dalje, kada posmatramo odnos digitalizacije i inovacija po zemljama OECD-a i BDP per capita dobijamo podatke iz tabele 6 .

Nakon ponavljanja provjere hipoteze navedenih testova dolazimo do istovjetnih zaključaka: ne možemo odbaciti prvu hipotezu, a odbacujemo drugu i treću hipotezu sa sigurnošću od 99\%. Prema tome, tehnologije

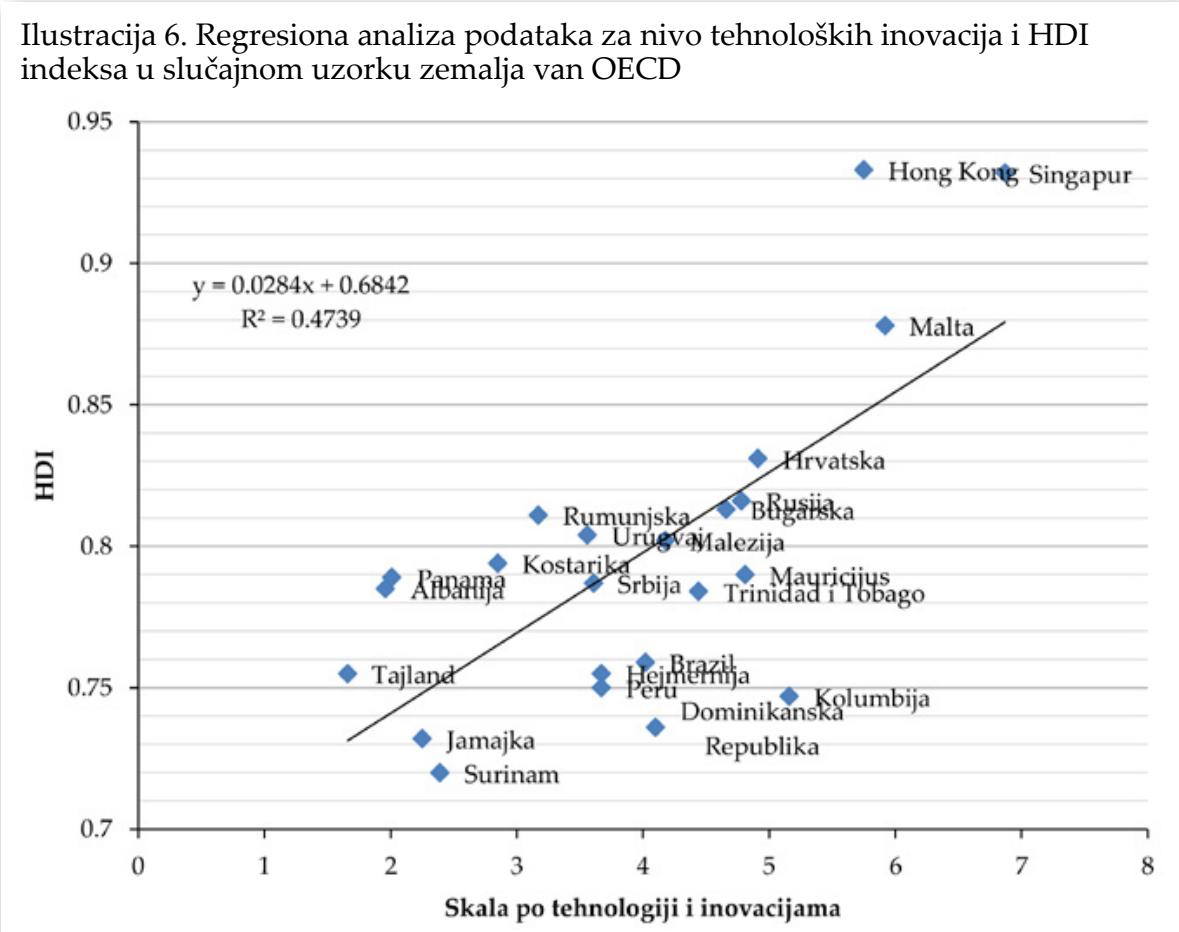

Izvor: Kalkulacija autora

0,7155027 što znači da postoji jaka direktna veza između nezavisne i zavisne varijable. $\mathrm{Na}$ ovom mjestu možemo ponuditi argumente za uzročno-posljedičnu vezu u oba smjera za sve promenljive i digitalizaciju. Na primjer, BDP stvara uslove za razvoj digitalizacije, dok digitalizacija privrede pospešuje rast BDP, što omogućava više izdvajanja za, recimo, školovanje koje podiže indeks ljudskog i inovacije ne utiču na FD indeks, ali utiču na HDI i na BDP per capita. Pokazali smo da postoji slaba veza odnosno slaba korelacija $(0,49 \%)$ između nivoa digitalizacije i inovacija i FD indeksa, a postoji determinacija od oko $24,65 \%$. Međutim, pokazali smo da postoji snažna korelacija između nivoa digitalizacije i inovacija i HD indeksa (korelacija od oko $68,88 \%$ i determinacija od oko $47,45 \%$ ), te 


\section{Results}

By analysing the relation between digitalisation and innovations across countries of OECD and FD index, we have obtained the table 4.

$R$ squared $\left(R^{2}\right)$ equals 0.137910 . That means that the independent variable (variable $X$ - the level of digitalisation and innovations) explains $13.8 \%$ of variable $\mathrm{Y}-\mathrm{FD}$ index. In other words, digitalisation and innovations affect around $13.9 \%$ of the financial market development. The multiple correlation coefficient (R) equals 0.371362188 which means that there is a weak direct relation between the independent and dependent variable.

Considering that the $\mathrm{p}$ value of 0.02575015 is higher than 0.01 , with a $99 \%$ certainty we cannot dismiss the hypothesis that "technology and innovations do not affect the FD index" and we can conclude that the "levels of digitalisation and innovations is not in a statistically significant relation with the FD index".
Table 8. Regression Analysis of Data on the Level of Technological Innovations and HDI in a Random Sample of Countries Outside the OECD

\begin{tabular}{|l|r|}
\hline \multicolumn{2}{|c|}{ Regression Statistics } \\
\hline R Square & 0.4739 \\
\hline Adjusted R Square & 0.450583 \\
\hline Standard Error & 0.040733 \\
\hline Observations & 24 \\
\hline Regression coefficient & 0.028382 \\
\hline Standard Error & 0.006368 \\
\hline F & 19.86252 \\
\hline Significance F & 0.000198 \\
\hline F crit & 2.737849 \\
\hline Test & dismissed \\
\hline
\end{tabular}

Source: Authors' calculation

$51.2 \%$ of variable $\mathrm{Y}-\mathrm{HD}$ index. In other words, digitalisation and innovations affect the level of human development index in a country, in the degree of about $52.2 \%$. The multiple correlation coefficient $(\mathrm{R})$ equals 0.7155027 which means that there is a strong direct relationship between

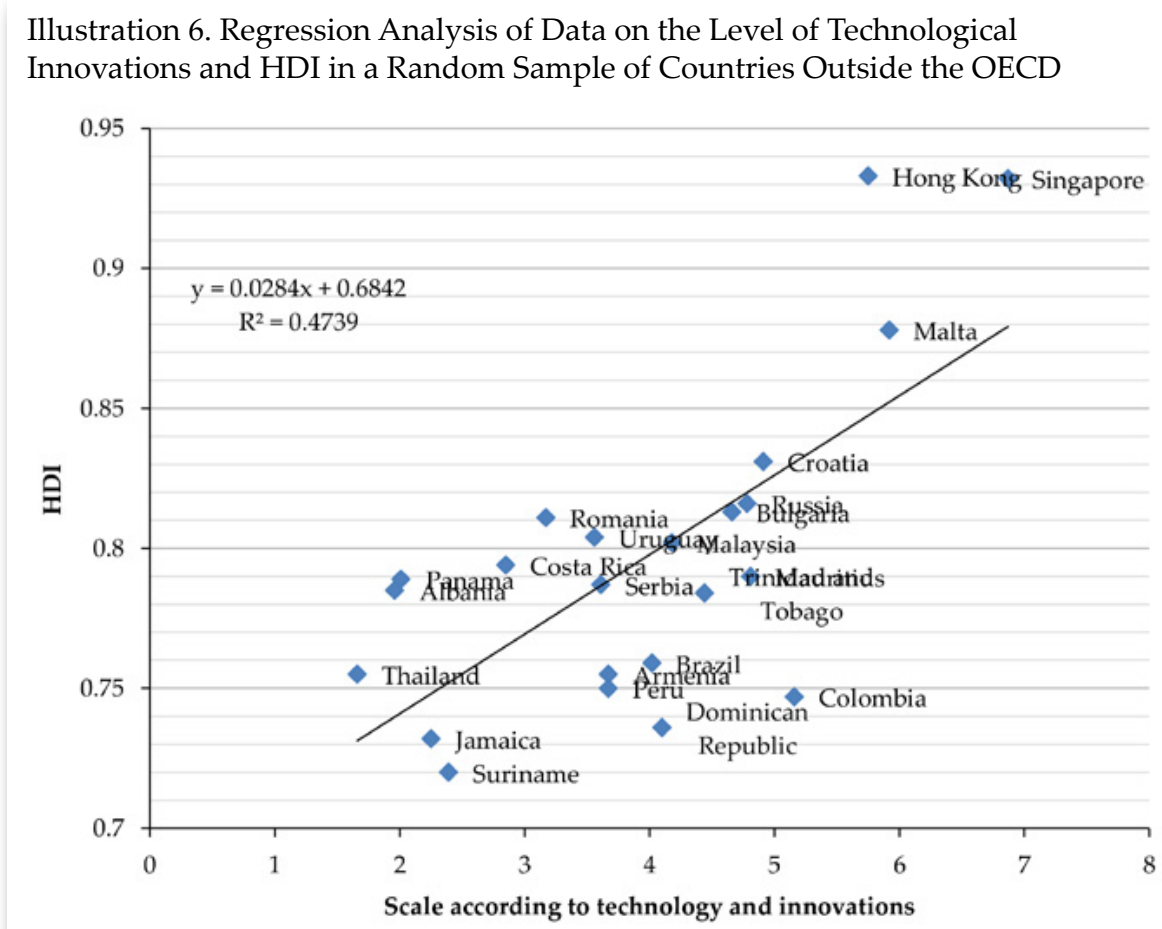

However, when we look at the relation between digitalisation and innovations by countries of OECD and the HD index, we obtain the table 5 .

$R$ squared $\left(R^{2}\right)$ equals 0.5119 . That means that the independent variable (variable $X$ - level of digitalisation and innovations) accounts for the independent and the dependent variable. At this moment we can offer arguments for the cause-and-effect relationship in both directions, for all variables and digitalisation. For example, GDP creates conditions for the development of digitalisation, while the digitalisation of economy facilitates the growth of GDP, enabling more assets 
Tabela 9. Regresiona analiza podataka za nivo tehnoloških inovacija i BDP per capita $\mathrm{u}$ slučajnom uzorku zemalja van OECD-a

\begin{tabular}{|l|r|}
\hline \multicolumn{2}{|c|}{ Regression Statistics } \\
\hline R Square & 0,4527 \\
\hline Adjusted R Square & 0,428576449 \\
\hline Standard Error & 10772,48644 \\
\hline Observations & 24 \\
\hline Regression coefficient & 0 \\
\hline Standard Error & 0 \\
\hline F & 18,25035364 \\
\hline Significance F & 0,00031045 \\
\hline F crit & 2,737849206 \\
\hline Test & odbacujemo \\
\hline Izvor: Kalkulacija autora & \\
\hline
\end{tabular}

nivoa digitalizacije i inovacija i BDP-a per capita (korelacija od oko 67,34\% i determinacija od oko $45,34 \%)$. slučajno izabranih zemalja za koje postoje parametri koje posmatramo (Prilog 2).

\section{Zaključna razmatranja}

Pokazali smo da nivo digitalizacije i inovacija ne utiče na nivo razvoja finansijskog tržišta. Ovu hipotezu smo potrvrdili na uzorku zemalja iz OECD-a i na uzorku manje razvijenih zemalja. S druge strane, pokazali smo da nivo digitalizacije i inovacija utiče na nivo humanog razvoja i na nivo BDP-a po glavi stanovnika.

Pokazali smo da digitalizacija i inovacije utiču tek oko 13,9\% na razvijenost finansijskog tržišta kod zemalja OECD-a. Koeficijent višestruke korelacije jednak je oko $37,13 \%$ što znači da postoji slaba direktna veza između nezavisne i zavisne varijable. $S$ obzirom na to

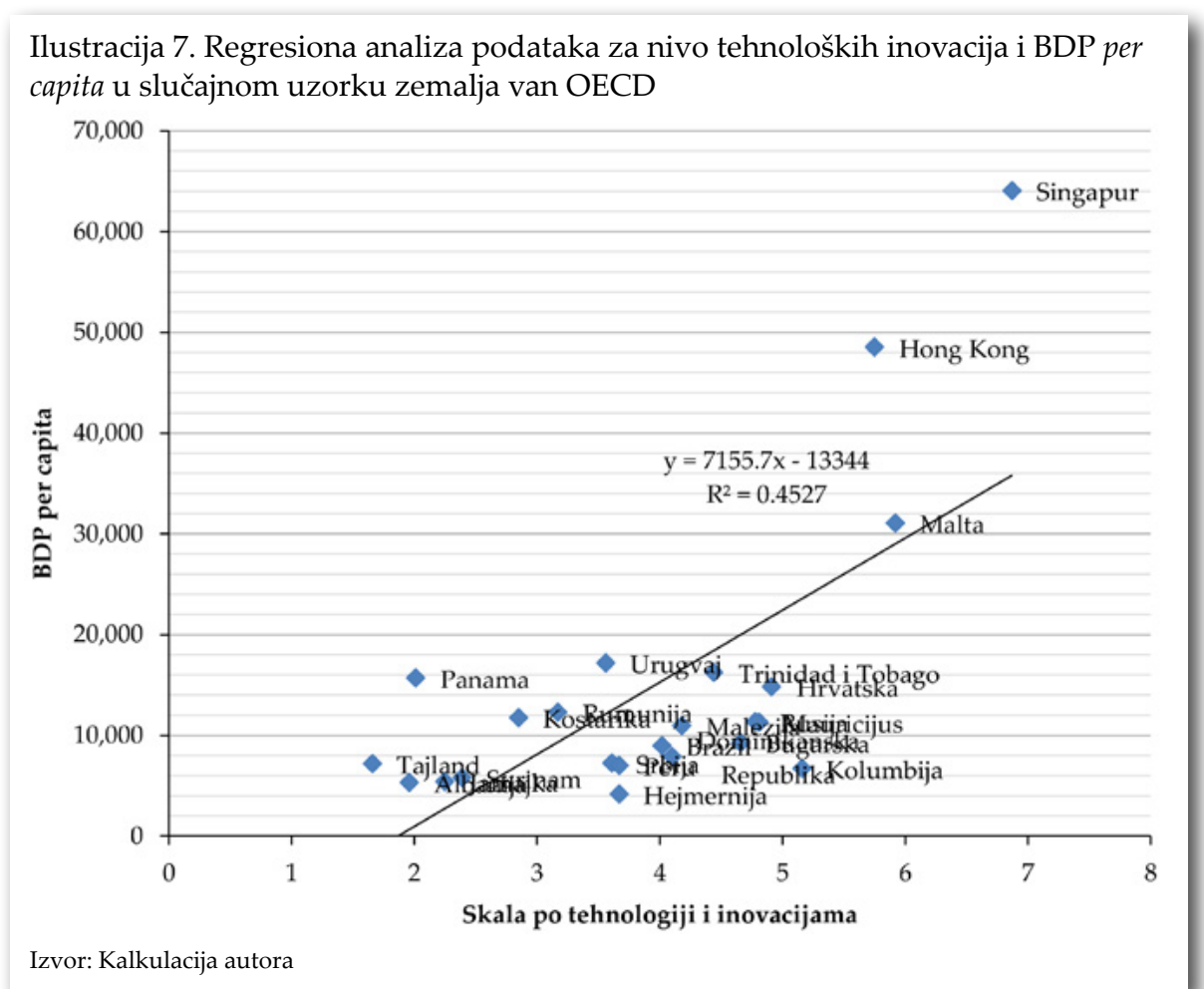

R kvadrat (R2) jednak je 0,1950785. To znači da nezavisna varijabla (varijabla X nivo digitalizacije i inovacija) objašnjava 19,5\% varijable $\mathrm{Y}$ - BDP per capita. Drugim riječima, digitalizacija i inovacije utiču oko 19,5\% na nivo BDP per capita u zemlji. Koeficijent višestruke korelacije (R) jednak je 0,44167693 što znači da postoji srednja direktna veza između nezavisne i zavisne varijable.

$S$ ciljem da još iste hipoteze provjerimo na drugom uzorku izabrali smo manji uzorak da je $p$ vrijednost 0,02575015 veća od 0,01 sa sigurnošću od $99 \%$ ne možemo da odbacimo hipotezu da ,tehnologije i inovacije ne utiču na FD indeks" i da zaključimo da nivo digitalizacije i inovacija stoje u statistički značajnoj vezi vezi sa FD indeksom.

S druge strane, pokazali smo da digitalizacija i inovacije utiču oko $52,2 \%$ na nivo indeksa humanog razvoja $u$ zemlji. Koeficijent višestruke korelacije (R) jednak je 0,7155027 što znači da postoji jaka direktna veza između 
for, for instance, education, which increases the human development index, while education also affects both GDP and digitalisation. The relation to the financial development is less obvious.

Considering that the $\mathrm{p}$ value, 0.0000009365 is significantly lower than 0.01 , we can dismiss with a 99\% certainty the hypothesis that "technology and innovations do not affect the HD index" and we can conclude that the level of digitalisation and innovations is related to the FD index, assuming that other variables remain unchanged.

In addition, when we look at the relation between digitalisation and innovations by countries of OECD and GDP per capita, we obtain the data from table 6.

After repeating the examination of hypotheses, we reach these conclusions: we cannot dismiss the first one and we will dismiss the second and third hypotheses with a 99\% certainty. Therefore, technology and innovations do not affect the FD index but they do affect HDI
Table 9. Regression Analysis of Data on the Level of Technological Innovations and GDP Per Capita in a Random Sample of Countries Outside the OECD

\begin{tabular}{|l|r|}
\hline \multicolumn{2}{|c|}{ Regression Statistics } \\
\hline R Square & 0.4527 \\
\hline Adjusted R Square & 0.428576449 \\
\hline Standard Error & 10772.48644 \\
\hline Observations & 24 \\
\hline Regression coefficient & 0 \\
\hline Standard Error & 0 \\
\hline F & 18.25035364 \\
\hline Significance F & 0.00031045 \\
\hline F crit & 2.737849206 \\
\hline Test & dismissed \\
\hline Source: Authors' calculation &
\end{tabular}

digitalisation and innovations and HDI (a 68.88\% correlation and about $47.45 \%$ determination), as well as the level of digitalisation and innovations and GDP per capita (a 67.34\% correlation and about $45.34 \%$ determination).

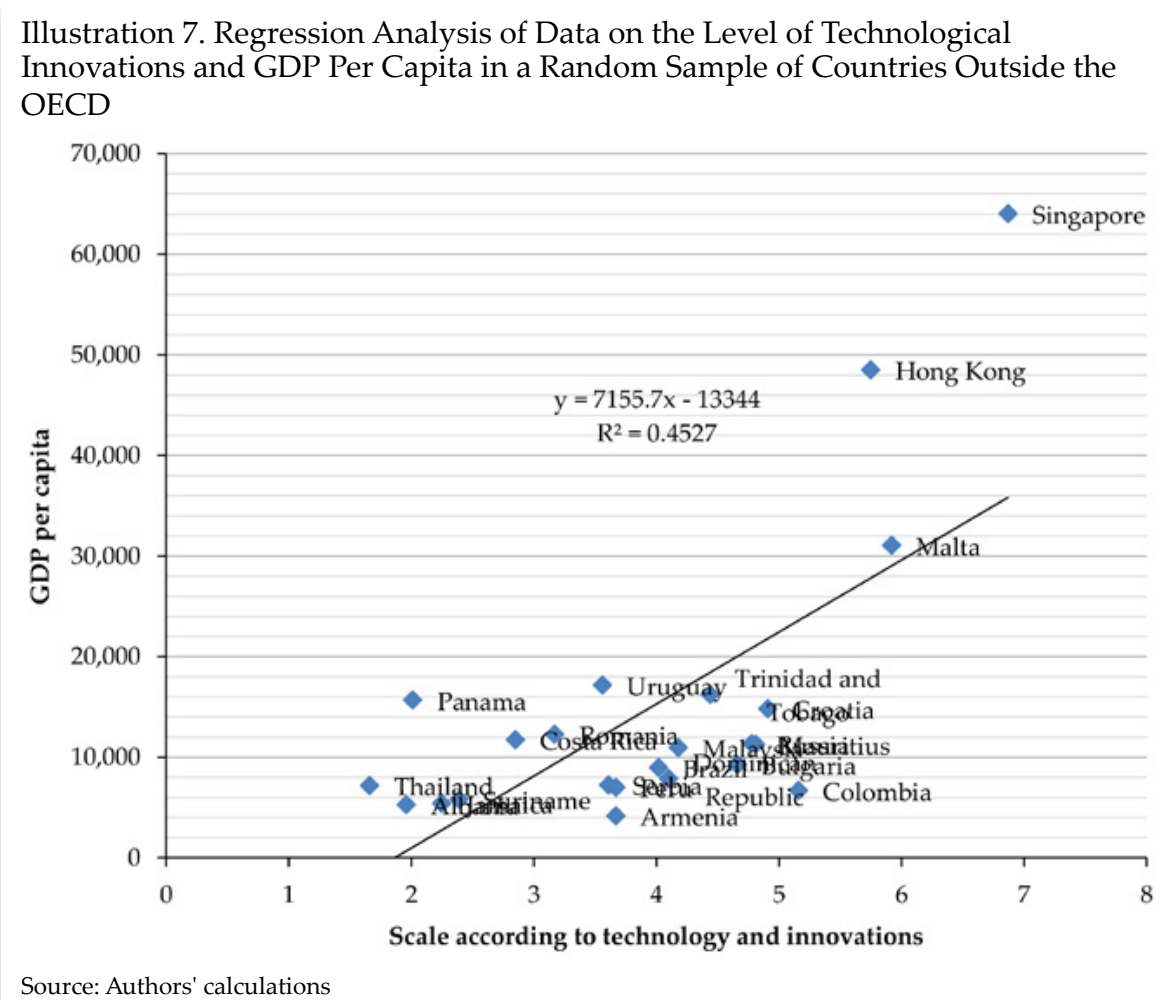

and GDP per capita. We have shown that there is a weak relationship, i.e. a low correlation $(0.49 \%)$ between the level of digitalisation and innovations and FDI and that there is a $24.65 \%$ determination. However, we have shown that there is a high correlation between the level of
R squared $\left(\mathrm{R}^{2}\right)$ equals 0.1950785 . That means that the independent variable ( $X$ variable-level of digitalisation and innovations) accounts for $19.5 \%$ of variable Y - GDP per capita. In other words, digitalisation and innovations affect the level of GDP per capita in the country in the degree of 
nezavisne i zavisne varijable. $S$ obzirom na to da je p vrijednost 0,0000009365 značajno manja od 0,01 sa sigurnošću od $99 \%$ možemo da odbacimo hipotezu da "tehnologije i inovacije ne utiču na HD indeks" i da zaključimo da nivo digitalizacije i inovacija veoma utiče na FD indeks pod pretpostavkom nepromjenjenih ostali varijabli.

Na kraju, digitalizacija i inovacije utiču oko 19,5\% na nivo BDP per capita u zemlji. Koeficijent višestruke korelacije (R) jednak je 0,44167693 što znači da postoji srednja direktna veza između nezavisne i zavisne varijable.

Iste zaključke dobili smo kada smo hipoteze testirali na slučajno odabranom uzorku zemalja koje nisu članice OECD-a.

Nakon ponavljanja provjere hipoteze navedenih testova dolazimo do istovjetnih zaključaka: ne možemo odbaciti prvu hipotezu, a odbacujemo drugu i treću hipotezu sa sigurnošću od 99\%. Prema tome, tehnologije i inovacije ne utiču na FD indeks ali utiču na HDI i na BDP per capita. Pokazali smo da postoji slaba veza odnosno slaba korelacija (0,49\%) između nivoa digitalizacije i inovacija i FD indeksa, a postoji determinacija od oko 24,65\%. Međutim, pokazali smo da postoji snažna korelacija između nivoa digitalizacije i inovacija i HD indeksa (korelacija od oko $68,88 \%$ i determinacija od oko $47,45 \%$ ), te nivoa digitalizacije i inovacija i BDP-a per capita (korelacija od oko 67,34\% i determinacija od oko 45,34\%).

Analiziranjem dosadašnjih trendova i pokazatelja nivoa razvoja digitalizacije finansijskih usluga, očigledno je da će finansijski posrednici u zemljama u razvoju biti prinuđeni da mijenjaju svoje poslovne modele i prilagođavaju ih ubrzanim promjenama na tržištu ili da sklapaju savezništva sa velikim tehnološkim kompanijama, kao i sa manjim firmama koje imaju komplementarna rješenja kao što ih imaju i banke. Osim toga, finansijski sektor će se razvijati prema otvorenim finansijskim uslugama, što će dodatno uticati na banke i ostale učesnike $\mathrm{u}$ finansijskoj industriji da dodatno prilagođavaju svoje poslovanje i usluge. U skladu sa tim, potrebno je regulativu mijenjati u pravcu podsticanja digitalizacije i inovacija i u finansijskom sektoru. Rezultati rada pokazuju da finansijske institucije u zemljama u razvoju, a prije svih banke - jer su one „najbliže“ stanovništvu, treba da djeluju što prije kako bi se pripremile za budućnost u kojoj će presudnu ulogu imati inovacije i nove tehnologije, gradeći prilagodljive i digitalno pripremljene poslovne modele koji će im pomoći da odgovore na sve izazove koji ih čekaju. Rad navodi i na preporuke za dalja istraživanja iz ove oblasti, jer je potrebno istražiti koje inovacije najviše doprinose određenim segmentima finansijskog sistema i društva.

Površna interpretacija rezultata ukazala bi na zaključak da niži $\mathrm{R}^{2}$ regresija koje imaju indeks finansijskog razvoja kao zavisnu promenljivu upućuje na dokaz slabije uzročnoposledične veze između inovacija i digitalizacije sa jedne i finansijskog razvoja sa druge strane, bez obzira $u$ kojem smjeru je ta veza (tj. od inovacija ka finansijskom razvoju, ili obrnuto). Međutim, istina je da i na jednu i na drugu od ove promenljive utiče mnoštvo faktora, i viši $\mathrm{R}^{2}$ regresija između recimo inovacija i ljudskog razvoja ne mora da znači da ove dve promenljive značajno utiču jedna na drugu, već može da znači i da ih determiniše neki treći faktor, kao što je na primjer BDP. Primjera radi, vrijednosni sistem dva brata može da bude gotovo isti, ali ne zato jer su uticali jedan na drugoga, već zato što su ih vaspitali isti roditelji. Prema tome, značaj koji se praksi pridaje $\mathrm{R}^{2}$ treba da bude manji nego što je akcenat $\mathrm{u}$ ovom istraživanju, ali i dalje vrijedi naglastiti da je on u regresijama sa indeksom finansijskog razvoja niži. Dakle, od međusobnih veza sve četiri promenljive ona sa indeksom finansijskog razvoja je najslabija - bez obzira na to da li je u pitanju rezultat slabijeg međusobnog uticaja navedenih promenljivih ili različitih drugih faktora koji $u$ radu nisu razmatrani, a eventualno ih determinišu.

Drugo, ostaje pitanje interpretacije statističkog značaja regresionih koeficijenata. $\mathrm{U}$ radu se insistira na tome da odnos inovacija sa finansijskim razvojem nije značajan, dok je odnos sa drugim promenljivima značajan. Takva interpretacija se zasniva na korišćenju praga od $1 \%$, dok nije održiva pri korišćenju praga od recimo 5\% koji bi u ovom kontekstu takođe bio sasvim prihvatljiv. Ovu činjenicu je važno naglasti da ne bismo prenaglasili značaj razlike koju smo analizom podataka pronašli.

$\mathrm{U}$ radu smo pokazali da veza inovacija i indeksa finansijskog razvoja jeste nešto slabija. 
about $19.5 \%$. The multiple correlation coefficient (R) equals 0.44167693, which means that there is an average direct relationship between the independent and dependent variable.

With the aim of examining the same hypotheses in a different sample, we have chosen a smaller sample of randomly chosen countries for which parameters observed exist (Supplement 2).

\section{Concluding Remarks}

We have proved that the level of digitalisation and innovations does not affect the level of the financial market development. This hypothesis was confirmed in a sample of countries outside OECD and in a sample of less developed countries. On the other hand, we have shown that the level of digitalisation and innovations affects the level of human development and the level of GDP per capita.

We have shown that digitalisation and innovations affect the financial market development in countries of OECD to a degree of only $13.9 \%$. The multiple correlation coefficient equals about $37.13 \%$, which means that there is a low direct correlation between the independent and the dependent variable. Considering that the $\mathrm{p}$ value of 0.02575015 is higher than 0.01 , with a $99 \%$ certainty we cannot dismiss the hypothesis that "technology and innovations do not affect the FD index" and conclude that the level of digitalisation and innovations are in a statistically significant correlation with the FD index.

On the other hand, we have shown that digitalisation and innovations affect the level of human development index in a country to a degree of about $52.2 \%$. The multiple correlation coefficient (R) equals 0.7155027 , which means that there is high direct correlation between the independent and dependent variable. Considering that the $\mathrm{p}$ value of 0.0000009365 is significantly lower than 0.01 , with a $99 \%$ certainty we can dismiss the hypothesis that "technology and innovations do not affect the HD index" and conclude that the level of digitalisation and innovations significantly affects the FD index, provided that other variables remain unchanged.

In the end, digitalisation and innovations affect the level of GDP per capita in a country, to a degree of about $19.5 \%$. The multiple correlation coefficient equals 0.44167693, which means that there is a moderate direct correlation between the independent and dependent variable.

We reached the same conclusions when we examined the hypotheses in a randomly chosen sample of countries outside the OECD.

After repeating the examination of the hypothesis, we reach the same conclusions: we cannot dismiss the first one and we dismiss the second and third hypotheses with a $99 \%$ certainty. Therefore, technology and innovations do not affect the FD index but they do affect HDI and GDP per capita. We have shown that there is a weak relationship, i.e. a low correlation $(0.49 \%)$ between the level of digitalisation and innovations and FDI and there is a $24.65 \%$ determination. However, we have shown that there is a high correlation between levels of digitalisation and innovations and HDI (a 68.88\% correlation and about $47.45 \%$ determination), as well as between the level of digitalisation and innovations and GDP per capita (a 67.34\% correlation and about $45.34 \%$ determination).

By analysing the existing trends and indicators of the level of development of financial services digitalisation, it is obvious that financial intermediaries in developing countries will be obliged to change their business models and adjust them to accelerated changes in the market, or to form alliances with large technological companies, as well as with smaller companies which have complementary solutions in the same manner as banks. Besides, the financial sector will develop towards openended financial services, which will lead banks and other participants in the financial industry to further adjust their business and services. In accordance with that, the regulations need to be changed in the direction of facilitating digitalisation and innovations in the financial sector, as well. The results of the paper indicate that financial institutions in developing countries, primarily banks, since they are the closest to the populations, should react as soon as possible in order to prepare for the future, when innovations and new technologies will have the principal role, by constructing adaptable and digitally prepared business models which will help them answer all the upcoming challenges. The paper also points to 
Međutim, to još uvijek ne znači da digitalizacija i inovacije nisu prodrle $u$ finansijski sektor onoliko koliko u ostatak privrede. Prvo, to bi moglo da znači i da digitalizacija i inovacije ne mijenjaju dubinu, pristup i efikasnost finansijskog sistema, iako su u njemu zastupljene. Drugo, to bi moglo da znači da digitalizacija jeste važna za finansijski razvoj, ali da stari indeks to ne mjeri dobro, dakle da bi možda trebalo menjati indeks koji se koristi. Treće, to bi moglo i da znači ono što se u radu naglašava, a to je da digitalizacija finansijskog sektora kaska za digitalizacijom ostatka privrede. Međutim i dve interpretacije su moguće. $\mathrm{S}$ tim u vezi ostavljen je i prostor budućim istraživanjima da razvrstaju koji je od ovih faktora odgovaran za manju vezu između inovacija i finansijskog razvoja u poređenju sa ljudskim razvojem ili BDP.

Bez sumnje, razvoj finansijskog sektora kaska za promjenama u digitalizaciji. Ideja se uklapa $\mathrm{u}$ nešto veću $\mathrm{p}$-vrijednost koeficijenta kojim digitalizacija objašnjava indeks finansijskog razvoja nego druge dvije promjenljive. Ova tvrdnja dobija na značaju kada znamo kako je konstruisan indeks finansijskog razvoja.
Naime, faktori koji na njega utiču, po samoj njegovoj definiciji, nisu u značajnoj vezi sa digitalizacijom, pa je otuda i veza slabija.

Rad pokazuje korelacije između digitalizacije i tehnoloških inovacija sa jedne strane i FD indeksa, HD indeksa i BDP per capita sa druge strane. Određivanje toga šta $\mathrm{u}$ kojoj meri uzrokuje ovo drugo ostavljeno je za buduća istraživanja.

Nakon ponavljanja provjere hipoteze navedenih testova dolazimo do istovjetnih zaključaka: ne možemo odbaciti prvu hipotezu, a odbacujemo drugu i treću hipotezu sa sigurnošću od $99 \%$. Prema tome, tehnologije i inovacije ne utiču na FD indeks, ali utiču na HDI i na BDP per capita. Pokazali smo da postoji slaba veza, odnosno slaba korelacija $(0,49 \%)$, između nivoa digitalizacije i inovacija i FD indeksa, gde postoji determinacija od oko 24,65\%. Međutim, pokazali smo da postoji snažna korelacija između nivoa digitalizacije i inovacija i HD indeksa (korelacija od oko $68,88 \%$ i determinacija od oko $47,45 \%$ ), te nivoa digitalizacije i inovacija i BDP-a per capita (korelacija od oko 67,34\% i determinacija od oko $45,34 \%)$. 
recommendations for further research in this field, because it is necessary to explore which innovations contribute the most to specific segments of the financial system and society.

A superficial interpretation of the results would lead to the conclusion that a lower $\mathrm{R}^{2}$ of regressions having the FDI as a dependent variable points to a weaker cause-andeffect relationship between innovations and digitalisation on the one hand and financial development on the other hand, disregarding the direction of the relationship (i.e. from innovation toward financial development, or vice versa). However, it is true that both these variables are affected by a variety of factors and a higher $\mathrm{R}^{2}$ of regressions between, for example, innovations and human development does not necessarily mean that these two variables significantly affect each other, but it might mean that they are determined by a third factor, like for example GDP. For example, the system of values followed by two brothers may be almost the same, but not because they influenced each other, but because they were raised by the same parents. Therefore, the significance assigned to $R^{2}$ should have less emphasis than in this research, but it is still worth to emphasise that it is lower in regressions with FDI. Hence, among the interrelationships of all four variables, the one with the FDI is the weakest - without considering if that is the result of a mutual weaker influence of these factors, or of other different factors not considered in this paper and potentially influential.

Secondly, the issue remains of the interpretation of the statistical significance of the regression coefficient. The paper insists on the relation between innovations and financial development is not significant, while the relation to other variables is substantial. Such interpretation is based on using a $1 \%$ threshold, while it is not sustainable when using, for example, a $5 \%$ threshold, which would also be quite acceptable in this context. This fact needs to be emphasised so as not to exaggerate the significance of the distinction found through data analysis.

In the paper we have shown that the relation of innovations and the FDI is somewhat weaker. However, that still does not mean that digitalisation and innovations have not entered the financial sector to the extent that they already permeate the rest of the economy. First, that might also mean that digitalisation and innovations do not change the depth, access and efficiency of the financial system, although they are present in it. Secondly, it might mean that digitalisation is important for financial development, but that the old index does not measure that properly, i.e. that potentially the index being used should be changed. Thirdly, it could also mean what is emphasised in the paper, i.e. that the digitalisation of the financial sector is falling behind in comparison with the digitalisation of the rest of the economy. However, two interpretations are also possible. In relation to that, there is some space for future research to determine which of these factors facilitates a weaker relationship between innovations and financial development, in comparison with the human development or GDP.

Undoubtedly, the financial sector's development is falling behind when it comes to changes in digitalisation. This idea fits in with the higher p-value of the coefficient, which digitalisation uses to explain the FDI over the other two variables. This claim becomes significant if we know how the FDI is constructed. Namely, the factors affecting it are not significantly linked to digitalisation by their very definition, hence the weaker relation.

The paper indicates correlations between digitalisation and technological innovations on the one hand and FD index, HD index and GDP per capita on the other hand. Determining what and to what extent determines the other is left for further research.

After repeating the examination of the hypothesis, we reached the same conclusions: we cannot dismiss the first one, and we dismiss the second and third hypotheses with a $99 \%$ certainty. Therefore, technology and innovations do not affect the FD index but they do affect HDI and GDP per capita. We have shown that there is a weak relationship, i.e. a low correlation $(0.49 \%)$ between the level of digitalisation and innovations and FDI, and there is $24.65 \%$ determination. However, we have shown that there is a high correlation between the levels of digitalisation and innovations and the HDI (a 68.88\% correlation and about $47.45 \%$ determination), as well as between the levels of digitalisation and innovations and GDP per capita (a $67.34 \%$ correlation and about $45.34 \%$ determination). 


\section{Literatura / References}

1. Aizenman, J., Jinjarak, Y., \& Park, D. (2015). Financial development and output growth in developing Asia and Latin America: A comparative sectoral analysis (No. w20917). National Bureau of Economic Research.

2. Amidžić, S., Kurteš, S., \& Rajčević, P. (2016). The impact of foreign aid on economic growth and competitiveness of the country. Business studies, 15-16.

3. Benazić, M., Rami, J. (2016). "Monetary policy and unemployment in Croatia." Economic research - Ekonomska istraživanja 29, br. 1 (2016): 1038-1049. Preuzeto 28.04.2019. sa https://hrcak.srce.hr/171786

4. Bjørnskov, C. (2007). Determinants of generalized trust: A cross-country comparison. Public choice, 130 (1-2),

5. Cihak, M., Demirgüç-Kunt, A., Feyen, E., \& Levine, R. (2012). Benchmarking financial systems around the world.World Bank Policy Research Working Paper. 6175:58. Preuzeto 28.04.2019. sa https://www. worldbank.org/en/publication/gfdr/data/ financial-structure-database

6. Demirgüç-Kunt, A., \& Levine, R. (2009). Finance and inequality: Theory and evidence. Annu. Rev. Financ. Econ., 1(1), 287-318. Preuzeto 11.02.2019. sa https://doi. org/10.3386/w15275

7. Dimitrova-Grajzl, V., \& Simon, E. (2010). Political trust and historical legacy: the effect of varieties of socialism. East European Politics and Societies, 24(2), 206-228.

8. Hoskisson, R. E., Eden, L., Lau, C. M., \& Wright, M. (2000). Strategy in emerging economies. Academy of management journal, 43(3), 249-267. Preuzeto 28.04.2019. sa https://journals.aom.org/doi/ abs/10.5465/1556394

9. Levine, R. (2005). Finance and growth: theory and evidence. Handbook of Economic Growth, 1, 865-934. u Philippe Aghion \& Steven Durlauf (ed.) 1(12):865-934.

10. Cifrić, I. (1996). Tranzicija i transformacija između norme i prakse. Socijalna ekologija, 5 (2), 135-153.

11. Dabla-Norris, M. E., \& Srivisal, M. N.
(2013). Revisiting the link between finance and macroeconomic volatility (No. 13-29). International Monetary Fund.

12. Dimitrova-Grajzl, V., \& Simon, E. (2010). Political trust and historical legacy: the effect of varieties of socialism. East European Politics and Societies, 24(2), 206-228.

13. Duvnjak, V. (2018). Coping with Crisis in the EU Periphery: The Case of Bosnia and Herzegovina. Journal of Balkan and Near Eastern Studies, 20(2), 196-210.

14. Fasnacht, D. (2009). Open Innovation in the financial services: growing through openness, flexibility and customer integration. Springer Science $\mathcal{E}$ Business Media.

15. Fetahagić, M. (2013). Aneks 1: Pokazatelji humanog razvoja za Bosnu i Hercegovinu.

16. Ghislandi, S., Sanderson, W. C., \& Scherbov, S. (2019). A simple measure of human development: The Human Life Indicator. Population and development review, 45(1), 219.

17. Grujić, M. (2019). The relationship of pension funds with financial markets development. Journal of Contemporary Economic and Business Issues, 6(2), 51-68.

18. Hoskisson, R. E., Eden, L., Lau, C. M., \& Wright, M. (2000). Strategy in emerging economies. Academy of management journal, 43(3), 249-267.

19. Huo, J., \& Hong, Z. (2013). The Rise of Service Science. In Service Science in China (pp. 39-68). Springer, Berlin, Heidelberg.

20. Laursen, K., \& Salter, A. (2006). Open for innovation: the role of openness in explaining innovation performance among UK manufacturing firms. Strategic management journal, 27(2), 131-150.

21. Lazarević, V, Đuričković, T. (2018). Digitalna ekonimija. Vulkan

22. Levine, R, and Demirguc-Kunt, A. (2009). Finance and inequality: theory and evidence.

23. Levine, R. (2005). Finance and growth: theory and evidence. Handbook of economic growth 1 (2005): 865-934. Posjećeno 28.04.2019. 
24. Mekinjić, B. (2019). The impact of industry 4.0 on the transformation of the banking sector. Journal of contemporary economics, $1(1)$.

25. National Bureau of Economic Research, Cambridge, Massachusetts. (2018.) Posjećeno 28.04.2019. URL: https://www. nber.org/data/international-finance/FinDev. xlsx

26. OECD. (2018). "Survey of Large Pension Funds and Public Pension Reserve Funds. Accessed April 2019. http://www.oecd. org/daf/fin/private-pensions/survey-largepension-funds.htm Pristupljeno 18.12.2018.

27. Pension Funds in Figures - OECD.org. (2019). Pension assets in the OECD area hit a record level in 2017. Pristupljeno 28.04.2019. http:// www.oecd.org/daf/fin/private-pensions/ globalpensionstatistics.htm

28. Šehović, D. (2017). Sajber otpornost finansijskih institucija. Bankarstvo Magazine, 46(4).

29. Tornjanski, V., Marinković, S., Lalić, N., \& ad Belgrade, E. (2014, June). Application of ANP method based on a BOCR model for decision-making in banking. In Proceedings of the XIV international symposium SYMORG 2014: New business models and sustainable competitiveness (pp. 107-116).

30. Tornjanski, V., Petrović, D., \& Milanović, M. (2016). Efekti IT i strategija otvorenih inovacija na inovacione $\mathrm{i}$ finansijske performanse $\mathrm{u}$ bankarstvu. Bankarstvo Magazine, (1).

31. Transparency International. 2016. "Corruption Perceptions Index 2016." Posjećeno 28.04.2019. URL: https://www. transparency.org/news/feature/corruption_ perceptions_index_2016

32. Trivić, J., \& Klimczak, Ł. (2015). The determinants of intra-regional trade in the Western Balkans. Zbornik radova Ekonomskog fakulteta u Rijeci: časopis za ekonomsku teoriju i praksu, 33(1), 37-66.

33. World econimic Forum. (2018). Readiness for the Future of Production Report www. weforum.org, 2018. 


\section{Prilog}

Tabela 10. Pregled korištnih pokazatelja za grupu zemalja iz OECD-a.

\begin{tabular}{|c|c|c|c|c|c|}
\hline Zemlja & Kontinent & $\begin{array}{c}\text { Skala po } \\
\text { tehnologiji i } \\
\text { inovacijama }\end{array}$ & FD Indeks & HDI & $\begin{array}{l}\text { BDP per } \\
\text { capita }\end{array}$ \\
\hline Australija & Australija & 5,81 & 0,8541623 & 0,939 & 56.352 \\
\hline Japan & Azija & 7,28 & 0,8684092 & 0,909 & 39.306 \\
\hline Južna Koreja & Azija & 8,39 & 0,855473 & 0,903 & 31.346 \\
\hline Austrija & Evropa & 6,8 & 0,6375566 & 0,908 & 51.509 \\
\hline Belgija & Evropa & 6,32 & 0,5801436 & 0,916 & 46.724 \\
\hline Kanada & Evropa & 6,43 & 0,8621565 & 0,926 & 46.261 \\
\hline Čile & Evropa & 2,73 & 0,4665055 & 0,843 & 16.079 \\
\hline Češka & Evropa & 6,96 & 0,3680759 & 0,888 & 22.850 \\
\hline Danska & Evropa & 7,34 & 0,643344 & 0,929 & 60.692 \\
\hline Estonija & Evropa & 6,74 & 0,329207 & 0,871 & 22.990 \\
\hline Finska & Evropa & 8,85 & 0,6626749 & 0,92 & 49.845 \\
\hline Francuska & Evropa & 7,05 & 0,7647089 & 0,901 & 42.878 \\
\hline Nemačka & Evropa & 7,94 & 0,6983447 & 0,936 & 48.264 \\
\hline Grčka & Evropa & 6,12 & 0,5393584 & 0,87 & 20.408 \\
\hline Mađarska & Evropa & 2,83 & 0,4355711 & 0,838 & 15.924 \\
\hline Island & Evropa & 6,29 & 0,542841 & 0,935 & 74.278 \\
\hline Irska & Evropa & 8,25 & 0,6912758 & 0,938 & 76.099 \\
\hline Izrael & Evropa & 7,46 & 0,568392 & 0,903 & 41.644 \\
\hline Italija & Evropa & 5,99 & 0,8011451 & 0,88 & 34.260 \\
\hline Letonija & Evropa & 5,36 & 0,2913639 & 0,847 & 18.032 \\
\hline Litvanija & Evropa & 5,87 & 0,2573722 & 0,858 & 19.143 \\
\hline Luksemburg & Evropa & 6,05 & 0,7459558 & 0,904 & 114.234 \\
\hline Meksiko & Evropa & 4,19 & 0,4091886 & 0,774 & 9.807 \\
\hline Holandija & Evropa & 8,68 & 0,7055485 & 0,931 & 53.106 \\
\hline Novi Zeland & Evropa & 6,81 & 0,6053087 & 0,917 & 41.267 \\
\hline Norveška & Evropa & 7,46 & 0,6906703 & 0,953 & 81.695 \\
\hline Poljska & Evropa & 5,71 & 0,4737788 & 0,865 & 15.431 \\
\hline Portugal & Evropa & 3,89 & 0,6911288 & 0,847 & 23.186 \\
\hline Slovačka & Evropa & 4,52 & 0,3241126 & 0,855 & 19.582 \\
\hline Slovenija & Evropa & 7,78 & 0,3851537 & 0,896 & 26.243 \\
\hline Španija & Evropa & 6,78 & 0,8811775 & 0,891 & 30.697 \\
\hline Švedska & Evropa & 7 & 0,7154871 & 0,933 & 53.873 \\
\hline Švajcarska & Evropa & 6,51 & 0,9374488 & 0,944 & 82.950 \\
\hline Turska & Evropa & 4,99 & 0,8270872 & 0,791 & 9.346 \\
\hline Velika Britanija & Evropa & 8,99 & 0,8244633 & 0,922 & 42.558 \\
\hline $\begin{array}{l}\text { Sjedinjene Američke } \\
\text { Države }\end{array}$ & $\begin{array}{l}\text { Sjeverna } \\
\text { Amerika }\end{array}$ & 6,99 & 0,8735749 & 0,924 & 62.606 \\
\hline
\end{tabular}

Izvor: Readiness for the Future of Production Report 2018; the National Bureau of Economic Research (2019), Organizacija za ekonomsku saradnju i razvoj (2019), Svjetski ekonomski forum (World Economic Forum, 2018) i Međunarodni monetarni fond (2019). 


\section{Supplement}

Table 10. An Overview of Used Indicators for the Group of Countries from OECD

\begin{tabular}{|c|c|c|c|c|c|}
\hline Country & Continent & $\begin{array}{c}\text { Scale according } \\
\text { to technology } \\
\text { and innovations }\end{array}$ & FD Index & HDI & GDP per capita \\
\hline Australia & Australia & 5.81 & 0.8541623 & 0.939 & 56,352 \\
\hline Japan & Asia & 7.28 & 0.8684092 & 0.909 & 39,306 \\
\hline South Korea & Asia & 8.39 & 0.855473 & 0.903 & 31,346 \\
\hline Austria & Europe & 6.8 & 0.6375566 & 0.908 & 51,509 \\
\hline Belgium & Europe & 6.32 & 0.5801436 & 0.916 & 46,724 \\
\hline Canada & Europe & 6.43 & 0.8621565 & 0.926 & 46,261 \\
\hline Chile & Europe & 2.73 & 0.4665055 & 0.843 & 16,079 \\
\hline Czech Republic & Europe & 6.96 & 0.3680759 & 0.888 & 22,850 \\
\hline Denmark & Europe & 7.34 & 0.643344 & 0.929 & 60,692 \\
\hline Estonia & Europe & 6.74 & 0.329207 & 0.871 & 22,990 \\
\hline Finland & Europe & 8.85 & 0.6626749 & 0.92 & 49,845 \\
\hline France & Europe & 7.05 & 0.7647089 & 0.901 & 42,878 \\
\hline Germany & Europe & 7.94 & 0.6983447 & 0.936 & 48,264 \\
\hline Greece & Europe & 6.12 & 0.5393584 & 0.87 & 20,408 \\
\hline Hungary & Europe & 2.83 & 0.4355711 & 0.838 & 15,924 \\
\hline Iceland & Europe & 6.29 & 0.542841 & 0.935 & 74,278 \\
\hline Ireland & Europe & 8.25 & 0.6912758 & 0.938 & 76,099 \\
\hline Israel & Europe & 7.46 & 0.568392 & 0.903 & 41,644 \\
\hline Italy & Europe & 5.99 & 0.8011451 & 0.88 & 34,260 \\
\hline Latvia & Europe & 5.36 & 0.2913639 & 0.847 & 18,032 \\
\hline Lithuania & Europe & 5.87 & 0.2573722 & 0.858 & 19,143 \\
\hline Luxembourg & Europe & 6.05 & 0.7459558 & 0.904 & 114,234 \\
\hline Mexico & Europe & 4.19 & 0.4091886 & 0.774 & 9,807 \\
\hline Netherlands & Europe & 8.68 & 0.7055485 & 0.931 & 53,106 \\
\hline New Zealand & Europe & 6.81 & 0.6053087 & 0.917 & 41,267 \\
\hline Norway & Europe & 7.46 & 0.6906703 & 0.953 & 81,695 \\
\hline Poland & Europe & 5.71 & 0.4737788 & 0.865 & 15,431 \\
\hline Portugal & Europe & 3.89 & 0.6911288 & 0.847 & 23,186 \\
\hline Slovakia & Europe & 4.52 & 0.3241126 & 0.855 & 19,582 \\
\hline Slovenia & Europe & 7.78 & 0.3851537 & 0.896 & 26,243 \\
\hline Spain & Europe & 6.78 & 0.8811775 & 0.891 & 30,697 \\
\hline Sweden & Europe & 7 & 0.7154871 & 0.933 & 53,873 \\
\hline Switzerland & Europe & 6.51 & 0.9374488 & 0.944 & 82,950 \\
\hline Turkey & Europe & 4.99 & 0.8270872 & 0.791 & 9,346 \\
\hline United Kingdom & Europe & 8.99 & 0.8244633 & 0.922 & 42,558 \\
\hline United States & North America & 6.99 & 0.8735749 & 0.924 & 62,606 \\
\hline
\end{tabular}

Source: Readiness for the Future of Production Report 2018; the National Bureau of Economic Research (2019), the Organisation for Economic Co-ordination and Development (2019), the World Economic Forum (2018) and the International Monetary Fund (2019). 
Tabela 11. Regresiona analiza podataka za nivo digitalizacije i HD indeksa za ostale izabrane i posmatrane zemlje

\begin{tabular}{|c|c|c|c|c|c|}
\hline Zemlja & Kontinent & $\begin{array}{c}\text { Skala po } \\
\text { tehnologiji i } \\
\text { inovacijama }\end{array}$ & FD Indeks & HDI & $\begin{array}{l}\text { BDP per } \\
\text { capita }\end{array}$ \\
\hline Mauricijus & Afrika & 4,81 & 0,4325249 & 0,79 & 11.281 \\
\hline Hong Kong & Azija & 5,75 & 0,7334458 & 0,933 & 48.517 \\
\hline Malezija & Azija & 4,18 & 0,6600142 & 0,802 & 10.942 \\
\hline Singapur & Azija & 6,87 & 0,7140425 & 0,932 & 64.041 \\
\hline Tajland & Azija & 1,66 & 0,7278029 & 0,755 & 7.187 \\
\hline Albanija & Evropa & 1,96 & 0,2099448 & 0,785 & 5.289 \\
\hline Jermenija & Evropa & 3,67 & 0,2474243 & 0,755 & 4.169 \\
\hline Bugarska & Evropa & 4,66 & 0,3779879 & 0,813 & 9.267 \\
\hline Hrvatska & Evropa & 4,91 & 0,4113067 & 0,831 & 14.816 \\
\hline Malta & Evropa & 5,92 & 0,5728436 & 0,878 & 31.058 \\
\hline Rumunija & Evropa & 3,17 & 0,308145 & 0,811 & 12.285 \\
\hline Rusija & Evropa & 4,78 & 0,5111977 & 0,816 & 11.327 \\
\hline Srbija & Evropa & 3,61 & 0,2664316 & 0,787 & 7.243 \\
\hline Brazil & Latinska Amerika & 4,02 & 0,5709821 & 0,759 & 8.968 \\
\hline Kolumbija & Latinska Amerika & 5,16 & 0,4423328 & 0,747 & 6.684 \\
\hline Kostarika & Latinska Amerika & 2,85 & 0,2749437 & 0,794 & 11.744 \\
\hline $\begin{array}{l}\text { Dominikanska } \\
\text { Republika }\end{array}$ & Latinska Amerika & 4,1 & 0,1801991 & 0,736 & 7.881 \\
\hline Jamajka & Latinska Amerika & 2,25 & 0,2715746 & 0,732 & 5.392 \\
\hline Panama & Latinska Amerika & 2,01 & 0,3529089 & 0,789 & 15.679 \\
\hline Peru & Latinska Amerika & 3,67 & 0,3750551 & 0,75 & 7.002 \\
\hline Surinam & Latinska Amerika & 2,39 & 0,2158981 & 0,72 & 5.799 \\
\hline Trinidad iTobago & Latinska Amerika & 4,44 & 0,3375334 & 0,784 & 16.223 \\
\hline Urugvaj & Latinska Amerika & 3,56 & 0,2499323 & 0,804 & 17.165 \\
\hline
\end{tabular}

Izvor: Readiness for the Future of Production Report 2018; the National Bureau of Economic Research (2019), Organizacija za ekonomsku saradnju i razvoj (2019), Svjetski ekonomski forum (World Economic Forum, 2018) i Međunarodni monetarni fond (2019). 
Table 11. Regression Analysis of Data on the Level of Digitalisation and HD Index for Other

Chosen and Observed Countries

\begin{tabular}{|c|c|c|c|c|c|}
\hline Country & Continent & $\begin{array}{c}\text { Scale according } \\
\text { to technology and } \\
\text { innovations }\end{array}$ & FD Index & HDI & GDP per capita \\
\hline Mauritius & Africa & 4.81 & 0.4325249 & 0.79 & 11,281 \\
\hline Hong Kong & Asia & 5.75 & 0.7334458 & 0.933 & 48,517 \\
\hline Malaysia & Asia & 4.18 & 0.6600142 & 0.802 & 10,942 \\
\hline Singapore & Asia & 6.87 & 0.7140425 & 0.932 & 64,041 \\
\hline Thailand & Asia & 1.66 & 0.7278029 & 0.755 & 7,187 \\
\hline Albania & Europe & 1.96 & 0.2099448 & 0.785 & 5,289 \\
\hline Armenia & Europe & 3.67 & 0.2474243 & 0.755 & 4,169 \\
\hline Bulgaria & Europe & 4.66 & 0.3779879 & 0.813 & 9,267 \\
\hline Croatia & Europe & 4.91 & 0.4113067 & 0.831 & 14,816 \\
\hline Malta & Europe & 5.92 & 0.5728436 & 0.878 & 31,058 \\
\hline Romania & Europe & 3.17 & 0.308145 & 0.811 & 12,285 \\
\hline Russia & Europe & 4.78 & 0.5111977 & 0.816 & 11,327 \\
\hline Serbia & Europe & 3.61 & 0.2664316 & 0.787 & 7,243 \\
\hline Brazil & Latin America & 4.02 & 0.5709821 & 0.759 & 8,968 \\
\hline Colombia & Latin America & 5.16 & 0.4423328 & 0.747 & 6,684 \\
\hline Costa Rica & Latin America & 2.85 & 0.2749437 & 0.794 & 11,744 \\
\hline Dominican Republic & Latin America & 4.1 & 0.1801991 & 0.736 & 7,881 \\
\hline Jamaica & Latin America & 2.25 & 0.2715746 & 0.732 & 5,392 \\
\hline Panama & Latin America & 2.01 & 0.3529089 & 0.789 & 15,679 \\
\hline Peru & Latin America & 3.67 & 0.3750551 & 0.75 & 7,002 \\
\hline Suriname & Latin America & 2.39 & 0.2158981 & 0.72 & 5,799 \\
\hline Trinidad and Tobago & Latin America & 4.44 & 0.3375334 & 0.784 & 16,223 \\
\hline Uruguay & Latin America & 3.56 & 0.2499323 & 0.804 & 17,165 \\
\hline
\end{tabular}

Source: Readiness for the Future of Production Report 2018; the National Bureau of Economic Research (2019), the Organisation for Economic Co-ordination and Development (2019), the World Economic Forum (2018) and the International Monetary Fund (2019). 